\title{
Responsible finance sukuk — can they bring societal value to a value-neutral market?
}

\author{
Edana Richardson*
}

\section{Key points}

- Conventional responsible finance provides investors with an opportunity to combine financial returns with broader societal impact in their investment activity. This emphasis on financial and extrafinancial considerations has led to suggestions that there are innate similarities between responsible finance and Islamic finance (as financial activity guided by religious principles).

- It has not been until recently, however, that the sukuk market has sought to establish its place within the wider responsible finance market. This has led to debut issuances of green, social and sustainability sukuk and the piecemeal development of precedents for future issuances.

- This article explores legal aspects of the nascent responsible finance sukuk market. In doing so, it provides an in-depth discussion of the legal structure of responsible finance sukuk issuances and reflects on claims that Islamic finance and responsible finance are naturally compatible.

\section{Introduction}

Responsible finance $^{1}$ has grown in prominence in recent years, with an influx of green, social and sustainability investment opportunities now available. By blending the goal of financial returns with concerns for broader societal impact, responsible finance covers financial activity targeting a non-exhaustive range of sectors that fit certain ethical, environmental, social and/or governance criteria. ${ }^{2}$ Like responsible finance,

\footnotetext{
* Edana Richardson, Lecturer in Law, Maynooth University, Ireland. The author would like to thank Dr Clíodhna Murphy and Jonathan Webb for their comments on a draft of this article. A portion of this article formed the basis for a paper presented at the Society for the Advancement of Socio-Economics (SASE) 30th Annual Conference, held at Doshisha University in Kyoto, Japan in June 2018. This article reflects the position as of April 2019. On 14 May 2019, MAF Sukuk Ltd, a special purpose vehicle incorporated in the Cayman Islands, issued USD600,000,000 4.638\% Trust Certificates guaranteed by Majid al Futtaim Holding LLC (the 'MAF Sukuk') under its USD1,500,000,000 Trust Certificate Issuance Programme. Based on a wakalah structure (a structure that is discussed in more detail below), trust assets comprising an asset portfolio of (i) income generating real estate and other tangible assets and (ii) commodity murabaha (also discussed in more detail below) investments are used to generate periodic returns for certificateholders. With the proceeds generated through this Islamic finance structure, the obligor will fund or refinance a portfolio of eligible projects falling within the categories of renewable energy, energy efficiency, sustainable water management and green buildings, all in accordance with the groups 'Green Finance Framework'. This was the first green sukuk transaction from Gulf Cooperation Council corporate and shares characteristics with other responsible finance sukuk issued to date. See, Final Terms dated 10 May 2019 for the issue by MAF Sukuk Ltd of USD600,000,000 4.638\% Trust Certificates. Due to the timing of this issuance immediately prior to the publication of this article, this article will focus on sukuk issued up to April 2019.

1 There is a lack of established terminology in the responsible finance market. For consistency, this article will adopt the broad label of 'responsible finance' to describe financial transactions that are structured to consider not simply financial criteria but also extra-financial standards targeting societal value maximization.

2 H Kent Baker and John R Nofsinger, Socially Responsible Finance and Investing: Financial Institutions, Corporations, Investors, and Activists (John Wiley \& Sons, Inc 2012) 3.
} 
contemporary Islamic finance is a relatively new addition to the global financial markets. This industry is arranged around financial activity that is structured to adhere to financial principles of Islamic law ${ }^{3}$ and entwines principles derived from religious teachings with financial objectives. While universally accepted standards of behaviour classified as 'ethical' or 'responsible' are difficult to identify in a contemporary economic context, ${ }^{4}$ the ethical code that is seen by some as inherent within Islamic law, and so within Islamic finance, ${ }^{5}$ has been highlighted as underpinning a natural compatibility between Islamic finance and responsible finance. ${ }^{6}$ Yet despite any suggested commonalities, the two market sectors have remained largely distinct and have overlapped only occasionally, something that is reflected in the sukuk market today.

Sukuk are Islamic capital markets instruments that evidence the proportionate interest of holders (who are referred to in this article as 'certificateholders') in underlying assets, revenues or services. ${ }^{7}$ In economic effect, sukuk today share characteristics with conventional bonds but provide an opportunity for market participants to issue, or to invest in, capital markets instruments that structurally align with financial principles of Islamic law. However, a review of the sukuk market to date suggests that the goals of those participating in issuances of sukuk certificates have not always focused directly on the impact of those instruments on society or collective well-being more generally. In practice, sukuk certificates endorsed as also being responsible finance occupy only a tiny segment of the sukuk market, where the majority of issuances appear to be value-neutral with respect to their wider societal impact. ${ }^{8}$

'Responsible finance sukuk', therefore, look to broaden the goals of Islamic capital markets activity to pursue both financial and extra-financial objectives, while still complying with Islamic law. Unlike sukuk generally, responsible finance sukuk have not been the subject of substantial academic analysis, particularly from a legal perspective. Instead, academic discourse has largely focused on the alignment of Islamic finance with responsible finance without considering how responsible finance instruments are structured in practice and their place within the broader Islamic finance market. This

3 The terms 'Islamic law' and 'shari'ah' are often used interchangeably. This article will use the term 'Islamic law' unless quoting directly or where the context requires otherwise. There is also no single correct means of expressing Arabic terms and sounds in the Latin alphabet. Throughout this article, quotations and the official names of products and organizations, which contain a transliteration of Arabic terms and use of italicization that are different from that used in this article, will be reproduced without adjustment.

4 Maria O’Brien Hylton, “'Socially Responsible” Investing: Doing Good versus Doing Well in an Inefficient Market’ (1992) 42(1) The American University Law Review 1, 6; Celia de Anca, 'Investing with Values: Ethical Investment versus Islamic Investment' in M Fahim Khan (ed), Islamic Banking and Finance in the European Union (Edward Elgar Publishing Limited 2010) $128,143$.

5 Islamic Research and Training Institute and others, Akram Laldin, Mustafa Adil and Ahmed Iskanderani (eds), Islamic Commercial Law Report 2018 (The International Shari'ah Research Academy for Islamic Finance, ISRA Consultancy Sdn Bhd and Islamic Research and Training Institute 2018) 7.

6 Gillian Rice, 'Islamic Ethics and the Implications for Business' (1999) 18 Journal of Business Ethics 345, 346; Jean-Yves Moisseron and Frederic Teulon, 'Is Morality-Based Islamic Economics an Answer to the Global Financial Crisis?' (2014) 27(1) Journal of King Abdulaziz University: Islamic Economics 125, 136; Nazrul Hazizi Noordin and others, 'Complying with the Requirements for Issuance of SRI Sukuk: The Case of Khazanah's Sukuk Ihsan' (2018) 9(3) Journal of Islamic Accounting and Business Research 415, 416.

7 Accounting and Auditing Organization for Islamic Financial Institutions, 'Shari'ah Standard No. (17), Investment Sukuk' in Shari'ah Standards (Accounting and Auditing Organization for Islamic Financial Institutions 2015) 463, 468.

8 Danial Idraki, 'Green Sukuk: Slow Progress in a Sector with Incredible Potential' (2016) 13(13) Islamic Finance News 15, 15. 
article addresses this under-researched area and presents a detailed discussion of the responsible finance sukuk market. It first introduces relevant aspects of conventional responsible finance bonds by considering the classification system used and standards applied. A range of responsible finance sukuk issuances are then discussed in chronological order, providing an in-depth description of their respective contractual structures. Finally, this article considers the application of Islamic law's ethical framework to contemporary Islamic finance and reflects on claims that Islamic finance and responsible finance are naturally compatible. In doing so, this article argues that Islamic finance today cannot be understood as being automatically aligned with responsible finance. However, the nascent responsible finance sukuk market could offer a mechanism through which Islamic finance market participants can move beyond finance that is value-neutral in its societal impact and towards a more active pursuit of greater collective well-being.

\section{Conventional responsible finance bonds}

Conventional responsible finance bonds ('responsible finance bonds') are structurally similar to standard bonds but direct proceeds generated by the issue of bond certificates towards the funding of projects ${ }^{9}$ that meet prescribed environmental, social or other ethical criteria. ${ }^{10}$ As most responsible finance bonds are fixed-income debt instruments, returns paid to holders (who are referred to in this article as 'bondholders') are typically ${ }^{11}$ assured and are not tied to the income generated by the funded project. ${ }^{12}$ As a result, responsible finance bonds provide bondholders with an opportunity to finance activity meeting particular societal objectives while still generating periodic interest payments and return of capital upon redemption of the bonds.

While the remit of an individual responsible finance transaction will be influenced by the subjective goals of transaction participants, ${ }^{13}$ the responsible finance bond market has developed a series of titles to attach to individual issuances of responsible finance bonds. The title used will typically relate to the nature of projects to be funded using the bond issue proceeds. Reflecting this, 'green bonds' are instruments whose issue proceeds are

9 The term 'project' is used in this article to cover enterprises, activities and projects that may be invested in.

10 See, for example, HSBC Holdings plc's USD1,000,000,000 sustainability bonds due 2023, whose use of proceeds aligns with the ICMA's Sustainability Bond Guidelines, while its eligible projects were classified based on specified United Nations Sustainable Development Goals.

11 Social impact bonds (discussed at text to $\mathrm{n} 17$ ), in contrast to other types of responsible finance bonds, typically do not guarantee returns to investors.

12 For example, the Türkiye Sınai Kalkınma Bankası A.Ş. issue of USD300,000,000 4.875\% Green/Sustainable Bonds due 2021 (Final Terms dated 16 May 2016) provide for investment of the proceeds into projects meeting climate change mitigation and climate change adaptation or sustainable infrastructure criteria. The rate of return paid pursuant to these bonds is fixed at $4.875 \%$ per annum payable semi-annually - the terms and conditions of the bonds confirm payment of this fixed rate of interest for the full tenor of the bonds and return of capital on redemption of the bonds [Condition 8.1, USD750,000,000 Global Medium Term Note Programme (base prospectus dated 19 April 2016)]. Non- or partial-recourse responsible finance bonds that are repaid with cash flows from an underlying project or project assets are possible, but are less common than responsible finance bonds that are full recourse to the issuer, see ICMA, Green Bond Principles (ICMA, 2018) app I.

13 Benjamin J Richardson, 'Climate Finance and Its Governance: Moving to a Low Carbon Economy Through Socially Responsible Financing’ (2009) 58(3) International and Comparative Law Quarterly 597, 598. 
applied to fund environmentally beneficial projects, ${ }^{14}$ 'social bonds' provide funding for projects that seek to address or mitigate identified social issues or to achieve positive social outcomes ${ }^{15}$ and 'sustainability bonds' fund projects that have both green and social objectives. ${ }^{16}$ 'Social impact bonds' represent a fourth category of responsible finance bonds, although they are structurally distinguishable from other bonds. ${ }^{17}$ Social impact bonds are outcomes-focused and performance-based, and as a result, they are not pure fixed-income debt instruments. Instead, they are structured so that payments made to bondholders are not assured but are contingent on the ability of a service provider to achieve pre-agreed outcomes from a funded project. ${ }^{18}$

Although the distinguishing characteristic of all responsible finance bonds is the connection between their use of proceeds and the green and/or social project being funded, the categories of projects that can benefit from this funding have not been clearly defined or universally accepted. ${ }^{19}$ Like conceptions of ethics more generally, what is meant by 'green' or 'social' in the context of responsible finance is a matter of interpretation. While some countries have introduced disclosure and certification standards for green bonds, ${ }^{20}$ a general absence of central regulation of what projects are eligible for funding has encouraged a market-led approach to voluntary self-governance. $^{21}$ For the green bond market, there are two sets of guidelines in place: the Green Bond Principles (the GBPs) ${ }^{22}$ issued by the International Capital Markets Association (ICMA) and the Climate Bonds Standard issued by the Climate Bond Initiative (the $\mathrm{CBI}){ }^{23}$ Both sets of guidelines emphasize transparency, issuer disclosure of eligible projects and independent verification of an issuance's green credentials. ${ }^{24}$ The guidelines

14 World Bank, 'What Are Green Bonds?' (World Bank, 2015) <http://documents.worldbank.org/curated/en/400251468187810398/ pdf/99662-REVISED-WB-Green-Bond-Box393208B-PUBLIC.pdf> accessed 30 April 2019.

15 ICMA, Social Bond Principles (ICMA, 2018) Social Bond Definition.

16 Clifford Chance LLP, “Make Our Planet Great Again”-Green, Social and Sustainability Bonds" (Clifford Chance LLP, 23 June 2017) 2 <https://www.cliffordchance.com/briefings/2017/06/_make_our_planetgreatagain-greensocialan.html> accessed 30 April 2019.

17 Shifali Baliga, 'Shaping the Success of Social Impact Bonds in the United States: Lessons Learned from the Privatization of U.S. Prisons' (2013) 63 Duke Law Journal 437, 439.

18 OEDC, 'Social Impact Bonds: State of Play \& Lessons Learnt' (2016) OECD Working Paper, $3<$ https://www.oecd.org/cfe/ leed/SIBs-State-Play-Lessons-Final.pdf> accessed 30 April 2019.

19 Adam Hedley and others, 'Green Bonds-How to Unlock Its Full Potential?' (Reed Smith LLP, 16 December 2015) Reed Smith Client Alert, $1<$ https://www.reedsmith.com/en/perspectives/2015/12/green-bonds-how-to-unlock-its-full-potential> accessed 30 April 2019.

20 See, for example, India (Securities and Exchange Board of India, Disclosure Requirements for Issuance and Listing of Green Debt Securities (30 May 2017, Circular No: CIR/IMD/DF/51/2017)) and China (People's Bank of China Announcement [2015] No 39). Belgium has also introduced a green bond framework (February 2018, The Kingdom of Belgium, 'Green OLO Framework'), although this is designed to enable the Belgian Debt Agency to issue green bonds, rather than acting as a national benchmark for Belgian issuers.

21 There have been calls for greater official standardization. See, for example, EU High-Level Expert Group on Sustainable Finance, Financing a Sustainable European Economy (European Commission 2018) $30<$ https:/ec.europa.eu/info/sites/info/files/ 180131-sustainable-finance-final-report_en.pdf > accessed 30 April 2019, noting that 'the EU should introduce an official EU Green Bond Standard'.

22 ICMA (n 12).

23 CBI, 'Climate Bonds Standard' (Version 2.1, 2017). The Climate Bonds Standard confirm at 3 '[f] ull alignment with the latest version of the [ICMA] Green Bond Principles.' As of the date of this article, the CBI has issued a draft version of the Climate Bonds Standard 3.0, which have been updated to align with the June 2018 update of the GBPs.

24 ICMA (n 12) s 1 Use of Proceeds, CBI, ibid, cl 3 Reporting Prior to Issuance. 
also set out categories of eligible green projects, including those linked to renewable energy and clean transportation. ${ }^{25}$ In the social bond market, the Social Bond Principles (the SBPs) ${ }^{26}$ issued by ICMA closely follow the GBPs and encourage transparency and standardization in social bond issuances. Eligible social projects under the SBPs include those providing affordable basic infrastructure and food security. ${ }^{27}$ Reflecting the fact that a project may not fit squarely within the individual categories of green or social, ICMA has also issued the Sustainability Bond Guidelines. ${ }^{28}$ These guidelines acknowledge that a bond can be classified as a sustainability bond if it complies with both the GBPs and the SBPs. ${ }^{29}$ Finally, unlike green, social and sustainability bonds, social impact bonds are not subject to market-led guidelines. The legitimacy of an intended social outcome and the level of disclosure provided to social impact bondholders are not, therefore, subject to standardization.

\section{Responsible finance sukuk}

In drawing parallels between Islamic finance and responsible finance, commentators have referred to ethical and moral values underpinning Islamic law, such as tawhid (unity), khilafah (vicegerency) and adalah (justice) to emphasize Islamic law's inherent concern for the Earth and society within it. ${ }^{30}$ Such principles are highlighted as presenting Islamic finance participants with a predetermined set of values upon which an ethical financial framework can be constructed. ${ }^{31}$ As Moghul notes, 'Islamic spirituality, in its norms as well as its practices, establishes a methodological framework and impetus to establish businesses and markets that support sustainability and social and environmental wellbeing. ${ }^{32}$ Reflecting these ethical principles, Islamic finance is said to provide 'a unique perspective and a value-based approach to finance ${ }^{33}$ where its participants are driven not solely by self-interest or personal maximization. Like conventional responsible finance, Islamic finance is presented as implementing a form of 'blended finance' under which both financial and broader societal goals are pursued.

In practice, as the conventional responsible finance sector has diversified and expanded, transactions that intentionally incorporate financial and societal motivations

\footnotetext{
25 ICMA ibid, s 1 Use of Proceeds, Climate Bond Initiative, ibid pt B (cls 9 and 10) Eligible Projects \& Assets.

26 ICMA (n 15).

27 Ibid, s 1 Use of Proceeds.

28 ICMA, 'Sustainability Bond Guidelines' (ICMA 2018).

29 ibid, Sustainability Bond definition.

30 Mahinaz El-Aasser, 'Responsible Investment and Islamic Finance: Can They Work Together?' (Islamic Finance News, 9 December 2015) <https://www.islamicfinancenews.com/responsible-investment-and-islamic-finance-can-they-work-together. html? share=email\&nb=1> accessed 30 April 2019; Michael S Bennett and Zamir Iqbal, 'How Socially Responsible Investing Can Help Bridge the Gap Between Islamic and Conventional Financial Markets' (2013) 6(3) International Journal of Islamic and Middle Eastern Finance and Management 211, 212; Umar F Moghul and Samir HK Safar-Aly, 'Green Sukuk: The Introduction of Islam's Environmental Ethics to Contemporary Islamic Finance' (2014) 27(1) The Georgetown International Environmental Law Review 1, 11; Moisseron and Teulon (n 6) 136.

31 Sabah Eldin Zaim, 'Islamic Economics as a System Based on Human Values' in Muazzam Ali (ed), Islamic Banks and Strategies for Economic Cooperation (New Century Publishers 1982) 15, 25.

32 Umar F Moghul, A Socially Responsible Islamic Finance: Character and the Common Good (Palgrave Macmillan 2017) 2. 
have been slow to feature in the mainstream Islamic finance market. ${ }^{34}$ Consistent with this trend, the sukuk market is dominated by instruments that use contractual structures to avoid contravening the Islamic legal prohibitions of riba (unjustified gain (most notably, interest) in a financial transaction), gharar (excessive risk), maysir (gambling) and haram (forbidden) activities but which have no wider societal objectives. Instead, these instruments address general funding requirements of the issuer or obligor. ${ }^{35}$

There have, to date, been only a small number of successfully issued responsible finance sukuk within global financial markets. These instruments are structured so that the proceeds from the issue of the sukuk certificates are, directly or (more typically) indirectly, invested in projects meeting predetermined extra-financial criteria. Periodic payments to certificateholders during the tenor of the sukuk (referred to in this article as 'periodic distributions'), and ultimate return of capital on redemption of the sukuk certificates, may in theory be influenced by the performance of a project with a defined societal purpose. This creates a link between certificateholders and funded projects. In practice, however, while Islamic finance is said to encourage the equitable sharing of profits and losses in financial activity, and to connect the generation of profit with production in the real economy, tying payments made to certificateholders to the economic success or failure of the funded project restricts the extent to which these payments can be made predictable and periodic. Reflecting the sukuk market's preference for fixed-income instruments, payments made to certificateholders of responsible finance sukuk have more typically been generated through a separate contractual arrangement between certificateholders and the issuer and are funded only indirectly from income linked to the funded project. ${ }^{36}$

The following section considers the responsible finance sukuk market. It outlines standards developed to facilitate growth of this market and provides a detailed discussion of a range of responsible finance sukuk issuances. ${ }^{37}$ This situates responsible finance sukuk

34 The Islamic microfinance sector has seen some grassroots development, see generally, Atif Hanif and Edana Richardson, 'Sharia-Compliant Microfinance' in Ranajoy Basu (ed), Microfinance: A Practitioner's Handbook (Globe Law and Business 2013 ) 63. 35 See, for example, Saudi Electricity Global Sukuk Company 2, issue of USD1,000,000,000 3.473\% certificates due 2023 and USD1,000,000,000 5.06\% certificates due 2043 (prospectus dated 4 April 2013), which provide that the obligor will use the net proceeds received pursuant to the sukuk transactions to finance the SEC Group's capital expenditures.

36 Debashis Dey and Stuart Ure, 'Kick-Starting the Market' (2015) 34 International Financial Law Review 36, 36.

37 In April 2018, UiTM Solar Power Sdn Bhd issued RM222,000,000 (approximately USD54,000,000) worth of green sukuk to fund the financing, design, engineering, procurement, construction, installation, testing, commissioning, ownership, operation and maintenance of a solar photovoltaic energy generating facility and associated facilities in Pahang, Malaysia [UiTM Solar Power Sdn Bhd, Other Terms and Conditions for the 'proposed issuance of sukuk under the shariah principle of murabahah (via tawarruq arrangement) of up to ringgit two hundred and forty million in nominal value', s 14 Definitions]. Certificateholders' investment, and the generation of returns paid to certificateholders, are based entirely on a commodity murabaha arrangement (discussed in more detail at text to $\mathrm{n}$ 61). As this structure is similar to that used in other Malaysian green sukuk, such as Sukuk QSP (defined below), it will not be discussed in detail in this article. Similarly, in February 2019, Pasukhas Green Assets Sdn Bhd issued RM200,000,000 (approximately USD48,000,000) worth of green sukuk to fund the acquisition, construction and other related expenses of a hydropower plant in Kelantan, Malaysia (Pasukhas Green Assets Sdn Bhd, Information Memorandum dated 27 February 2019 for the 'proposed issue of, offer for subscription or purchase of, or invitation to subscribe for or purchase of Islamic medium term notes pursuant to an Islamic medium term note programme of RM200.0 million in nominal value under the shariah principle of Wakalah bi al-istithmar together with murabahah (via tawarruq arrangement)'), s 8(4)_Principal Terms and Conditions of the Asean Green SRI Sukuk Programme, Facility description. As the wakalah, commodity murabaha structure used is similar to that found in other responsible finance sukuk, such as the Sukuk SKSB (defined below), it will not be discussed in detail in this article. 
as a segment of the broader Islamic finance market and discusses, in an academic context, the contractual structures used in these instruments. In each case, the underlying Islamic finance agreements are considered, together with the nature of the eligible project. This section also outlines how certificateholders' periodic distributions are generated, the nature of certificateholders' relationship with the funded project and the manner in which capital is ultimately returned to certificateholders.

\section{Responsible finance sukuk standards}

Unlike the market-led growth of the responsible finance bond market, issuances of responsible finance sukuk have generally followed specific government-led initiatives. A 'top-down'38 approach to encouraging the responsible finance sukuk market is reflected in the development of relevant standards. ${ }^{39}$ The first responsible finance sukuk standards were published in 2014 by the Securities Commission of Malaysia (the SC, a statutory body with authority to oversee, regulate and develop the Malaysian capital markets) as part of its broader goal of promoting socially responsible finance and investment. ${ }^{40}$ These standards (the 'SC's SRI Sukuk Standards') are built into Malaysia's existing regulatory framework for sukuk ${ }^{41}$ and are mandatory for issuances of responsible finance sukuk within Malaysia. ${ }^{42}$ The threshold requirement for classification as a sukuk complying with the SC's SRI Sukuk Standards is that the use of proceeds from the issue of the sukuk certificates is directed towards funding eligible projects. ${ }^{43}$ This list of eligible projects is finite and prescriptive and includes both environmentally friendly projects and projects

38 In 2012, the Green Sukuk and Working Party (the GSWP) was established by the CBI, the Clean Energy Business Council (MENA) and the Gulf Bond and Sukuk Association. The stated aims of the GSWP are to promote and develop sukuk products that are compliant with Islamic law and are also structured to invest in climate change solutions. Climate Bonds Initiative, 'Green Sukuk' <https://www.climatebonds.net/projects/facilitation/green-sukuk> accessed 30 April 2019. Since then, the market has largely followed government-led initiatives. For example, in 2014, the Dubai Supreme Council of Energy and the World Bank (in its capacity as the International Bank for Reconstruction and Development) signed an advisory services agreement to develop Dubai's green investment programme, including the issuance of responsible finance sukuk, World Bank, 'Dubai Supreme Council of Energy and World Bank Partner to Design a Funding Strategy for Dubai's Green Investment Program' (World Bank, 15 April 2014 ) $<$ https://www.worldbank.org/en/news/press-release/2014/04/15/dubai-supreme-council-of-energy-and-world-bank-partner-todesign-a-funding-strategy-for-dubais-green-investment-program> accessed 30 April 2019.

39 Malaysia has also announced tax incentives to attract issuers green sukuk, such as a tax deduction until 2020 on issuance costs of certain green sukuk. For a discussion of Malaysia's approach to green bond and sukuk generally, see, International Finance Corporation and Climate Bonds Initiative (prepared for the Sustainable Banking Network Green Bond Working Group), 'Creating Green Bond Markets-Insights, Innovations, and Tools from Emerging Markets' (IFC, October 2018), <https://www.ifc. org/wps/wcm/connect/55e5e479-b2a8-41a6-9931-93306369b529/SBN+Creating+Green+Bond+Markets+Report+2018.

pdf?MOD=AJPERES $>$ accessed 30 April 2019.

40 This goal was initially set out in Securities Commission Malaysia, 'Capital Market Masterplan 2' (Securities Commission Malaysia 2011) para 3.1.4. Securities Commission Malaysia and World Bank Group, Islamic Green Finance; Development, Ecosystem and Prospects (Securities Commission Malaysia, March 2019), 35 <https://www.sc.com.my/api/documentms/ download.ashx?id=a86707ce-07e0-4c75-9e45-7ad7bca6f540> accessed 30 April 2019.

41 In the 2014 revised edition of the SC's 'Guidelines on Sukuk', a new pt D was added to address the additional requirements to be met for the issue, offering an invitation to subscribe or purchase 'sustainable and responsible investment (SRI) sukuk' [Securities Commission Malaysia, 'Guidelines on Sukuk' (Revised 28 August 2014) pt D]. The Guidelines on sukuk have since been superseded by the SC's 'Guidelines on Unlisted Capital Market Products under the Lodge and Launch Framework' [SC-GL/4-2015 (R3-2018) first issued 9 March 2015, revised 11 October 2018] ('SC LOLA Guidelines') and the SC's 'Guidelines on Issuance of Corporate Bonds and Sukuk to Retail Investors' [SC-GL/5-2015 (R3-2018) first issued 9 March 2015, revised 11 October 2018] ('SC Retail Guidelines'), each of which has a separate chapter dedicated to responsible finance sukuk.

42 SC Retail Guidelines, ibid, para 1.06.

43 SC LOLA Guidelines ( $\mathrm{n}$ 41), pt 3, para 7.02; SC Retail Guidelines (n 41), para 20.02. 
with positive social objectives. ${ }^{44}$ The SC's SRI Sukuk Standards also detail the level of disclosure, reporting and independent assessment required for issuances of responsible finance sukuk. ${ }^{45}$

In 2017, the Association of Southeast Asian Nations (ASEAN) Capital Markets Forum, an intergovernmental forum for regulatory authorities from ASEAN countries, published the ASEAN Green Bond Standards. ${ }^{46}$ These standards seek to 'enhance transparency, consistency and uniformity of ASEAN Green Bonds ${ }^{37}$ while facilitating the development of specifically designated ASEAN green bonds and sukuk. ${ }^{48}$ The ASEAN Green Bond Standards are based on ICMA's GBPs with respect to eligible projects, issuer disclosure and independent verification, although unlike the GBPs, the ASEAN Green Bond Standards specifically confirm that fossil fuel power generation projects cannot be funded using ASEAN green bonds or sukuk. ${ }^{49}$ In October 2018, the ASEAN Green Bond Standards were followed by the publication of the ASEAN Social Bond Standards and the ASEAN Sustainability Bond Standards.

Following the publication of these standards, the responsible finance sukuk market has gained some momentum, with most of the recent responsible finance sukuk issuances structured specifically to align with published standards.

\section{Responsible finance sukuk issuances-an analysis}

\section{Social sukuk}

The first responsible finance sukuk issuances provided funding for projects with socially beneficial objectives. In each case, these social sukuk were issued by a multilateral or government-backed entity, rather than a corporate issuer. This lack of corporate issuers reflects, perhaps, the nature of the projects that have been funded through the issue of social sukuk and the level of government involvement in these projects. Nevertheless, these social sukuk structures were pioneering within the responsible finance sukuk market and, in the case of the Sukuk Ihsan (defined below), were the first sukuk certificates to be approved under responsible finance sukuk standards.

\section{Sukuk IFFIm:}

In 2014, 2015 and 2019, the International Finance Facility for Immunisation Company (IFFIm) acted as obligor for three standalone issues of sukuk certificates (the 2014 and 2015 issuances together, the 'Sukuk IFFIm'), ${ }^{50}$ in each case through a special purpose vehicle (SPV). ${ }^{51}$ Although presented as the first 'green' ${ }^{52}$ or 'socially responsible

\footnotetext{
44 SC LOLA Guidelines, ibid, pt 3, para 7.04; SC Retail Guidelines, ibid, para 20.04.

45 SC LOLA Guidelines, ibid, pt 3, paras 7.06 and 7.07; SC Retail Guidelines, ibid, para 20.07. The Guidelines do not identify the nature or content of this assessment.

46 ASEAN Capital Markets Forum, ASEAN Green Bond Standards (ACMF 2017, updated 2018).

47 Ibid 3 .

48 Ibid 3. The ASEAN Green Bond Standards define 'ASEAN Green Bonds' as meaning bonds and sukuk that comply with the ASEAN Green Bond Standards, ASEAN Capital Markets Forum (n 46) 6.

49 Ibid 9.

50 IFFIm Sukuk Company Limited USD500,000,000 certificates due 2017, IFFIm Sukuk Company II Limited USD200,000,000 certificates due 2018 and IFFIm Sukuk Company III Limited USD50,000,000 certificates due 2022. The 2019 issuance by IFFIm Sukuk Company III Limited was an unlisted private placement with the Islamic Development Bank as the sole certificateholder. As
} 
investment $^{53}$ sukuk, the Sukuk IFFIm do not optically display characteristics of responsible finance instruments. The descriptions of the Sukuk IFFIm do not label the sukuk as green, social or sustainability sukuk and the use of proceeds of each issue provides simply that ' $[\mathrm{t}]$ he net proceeds received by IFFIm . . . will be applied by IFFIm to fund its general operations. ${ }^{54}$ However, the nature of IFFIm and its general operations facilitate the socially beneficial nature of the Sukuk IFFIm. ${ }^{55}$

IFFIm is a multilateral development institution and registered charity whose primary function is to provide funding for the programmes of Gavi, an international organization responsible for operational activities related to immunization, vaccine procurement and health system strengthening programmes in developing countries. ${ }^{56}$ Following Gavi's

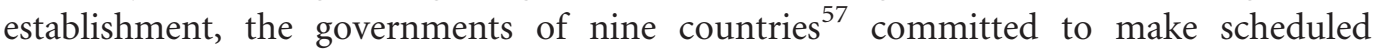
payments for up to 20 years to fund Gavi's operations (these commitments together, the 'Grant Agreements'). ${ }^{58}$ The right to receive these payments was assigned to IFFIm, who was tasked with procuring immediate and upfront funding for Gavi's programmes. ${ }^{59}$ By applying the proceeds from the issue of sukuk to fund its 'general operations', therefore, IFFIm directs those proceeds to Gavi to be used for programmes with stated social objectives. $^{60}$

Periodic distributions made to certificateholders are generated through a sukuk structure based on a commodity murabaha arrangement (which involves a sales agreement, where the purchase price of commodities is payable on a deferred and marked-up basis). ${ }^{61}$ Pursuant to this structure, the Sukuk IFFIm were issued to certificateholders. The issuer then declared a trust in favour of certificateholders over its

the documentation for this issuance was not publicly available as of the date of this article, the following discussion will focus on the 2014 and 2015 issuances.

51 IFFIm Sukuk Company Limited, IFFIm Sukuk Company II Limited and IFFIm Sukuk Company III Limited, respectively.

52 Dey and Ure (n 36) 36.

53 Michael Bennett, "'Vaccine Sukuks: Islamic Securities Deliver Economic and Social Returns" World Bank—Voices and Views: Middle East and North Africa' (World Bank, 29 October 2015) <http://blogs.worldbank.org/arabvoices/vaccine-sukuks-islamicsecurities-deliver-economic-and-social-returns> accessed 30 April 2019.

54 Private Placement Memorandum dated 1 December 2014, IFFIm Sukuk Company Limited issue of USD500,000,000 Trust Certificates due 2017 ('IFFIm I PPM'), 46 Use of Proceeds; Private Placement Memorandum dated 28 September 2015, IFFIm Sukuk Company II Limited issue of USD200,000,000 Trust Certificates due 2018 ('IFFIm II PPM'), 46 Use of Proceeds.

55 With respect to conventional IFFIm 'vaccine' bonds, IFFIm has specifically confirmed that 'IFFIm complies with all four components of the SBPs', IFFIm, 'Socially Responsible Investing through Vaccine Bonds', <https://www.iffim.org/bonds/vaccinebonds/> accessed 30 April 2019.

56 The Memorandum of Association of IFFIm confirms that 'the Charity [IFFIm]'s objects ... are to promote the effective use of the resources of GAVI Organisations for Charitable Purposes [defined as the relief of sickness and the promotion, protection and preservation of good health among people in developing countries] for the benefit of the public by providing services and facilities which will assist GAVI Organisations to raise funds', para 3, Memorandum of Association of International Finance Facility for Immunisation Company (23 June 2006, lodged with the UK Companies House on 6 October 2006).

57 The Republic of France, the Republic of Italy, the Kingdom of Norway, the Republic of South Africa, the Kingdom of Spain, the Kingdom of Sweden, the UK, the State of the Netherlands and the Commonwealth of Australia.

58 The GAVI Fund Affiliate was the original grantee of the scheduled payments. Pursuant to a Deed of Novation, on 8 February 2013, the GAVI Fund Affiliate transferred by novation all of its duties, liabilities, covenants, undertakings and obligations under each grant agreement to Gavi, IFFIm I PPM, 52 and IFFIm II PPM, 52.

59 IFFIm I PPM, 49 and IFFIm II PPM, 49.

60 Ibid.

61 IFFIm I PPM, 17 and IFFIm II PPM, 17. The commodity murabaha used in these structures can also be referred to as tawarruq. 
rights, title, interest and benefit in, to and under the transaction documents related to the particular issue of Sukuk IFFIm, any monies standing in a defined account, and in each case, any related proceeds generated. ${ }^{62}$ This gives certificateholders an undivided proportionate ownership interest in those assets. ${ }^{63}$

Pursuant to the commodity murabaha arrangement, the issuer (as trustee) purchases commodities for cash at a price equal to the proceeds from the relevant issue of Sukuk IFFIm certificates. ${ }^{64}$ The issuer sells these commodities to IFFIm at their original cost price, plus a pre-agreed profit, payable on the periodic distribution date. ${ }^{65}$ The trustee uses the cost price-plus-profit paid by IFFIm to purchase further commodities and (using the profit element of the payment only) to pay periodic distributions to certificateholders. ${ }^{66}$ Upon receipt of the commodities, IFFIm immediately on-sells these for cash at their original cost price. ${ }^{67}$ The commodity murabaha process then repeats on each periodic distribution date until maturity or early redemption of the relevant Sukuk IFFIm certificates. $^{68}$ On redemption of the Sukuk IFFIm certificates, the full cost price-plusprofit due from IFFIm with respect to the last sale of commodities is used to pay certificateholders the aggregate outstanding principal amount of the relevant Sukuk IFFIm and all accrued but unpaid periodic distributions. ${ }^{69}$ No further commodities will be purchased. ${ }^{70}$

The commodity murabaha structure used in the Sukuk IFFIm provides certificateholders with periodic payments throughout the tenor of each issue and assured repayment of capital on redemption of the Sukuk IFFIm certificates. Concurrently with this, the net proceeds received by IFFIm from the commodity murabaha must be used by IFFIm to fund its general operations. ${ }^{71}$ While the sukuk issue proceeds will, therefore, ultimately be used for the social purposes for which IFFIm operates, they do so indirectly.

62 IFFIm I PPM, Condition 5 The Trust and the Murabaha Arrangements and IFFIm II PPM, Condition 5 The Trust and the Murabaha Arrangements.

63 IFFIm I PPM, Condition 4.1 Status and Limited Recourse-Status and IFFIm II PPM, Condition 4.1 Status and Limited Recourse-Status.

64 IFFIm I PPM, Condition 1 Definitions and Interpretation—Definition of 'Cost Price' and IFFIm II PPM, Condition 1 Definitions and Interpretation-Definition of 'Cost Price'.

65 The amount of profit payable is pegged to the London Interbank Offered Rate and will fluctuate during the tenor of the relevant series of Sukuk IFFIm. IFFIm I PPM, Condition 1 Definitions and Interpretation-Definition of 'Murabaha Profit' and Condition 7.2 Periodic Distributions_Benchmark Rate and IFFIm II PPM, Condition 1 Definitions and Interpretation-Definition of 'Murabaha Profit' and Condition 7.2 Periodic Distributions-Benchmark Rate.

66 IFFIm I PPM, 18 and IFFIm II PPM, 18.

67 IFFIm I PPM, 17 and IFFIm II PPM, 17. In practice, the parties have agreed to net off amounts due in respect of the payment obligations, and so, on each periodic distribution date, IFFIm will only be required to pay to the issuer the profit element of the amount due.

68 Early redemption of the certificates can occur following the occurrence of a dissolution event (that is, an event of default) (pursuant to IFFIm I PPM, Condition 9.3 Redemption and Dissolution of the Trust-Dissolution Following a Dissolution Event and Condition 13 Dissolution Events and IFFIM II PPM, Condition 9.3 Redemption and Dissolution of the Trust-Dissolution Following a Dissolution Event and Condition 13 Dissolution Events) or following the occurrence of an early redemption for tax reasons (pursuant to IFFIm I PPM, Condition 9.2 Early Dissolution for Taxation Reasons and IFFIm II PPM, Condition 9.2 Early Dissolution for Taxation Reasons).

69 IFFIm I PPM, 18 and Condition 1 Definitions and Interpretation-Definition of 'Dissolution Amount' and IFFIm II PPM, 18 and Condition 1 Definitions and Interpretation-Definition of 'Dissolution Amount'.

70 IFFIm I PPM, 18 and IFFIm II PPM, 18.

71 IFFIm I PPM, 46 Use of Proceeds and IFFIm II PPM, 46 Use of Proceeds. 
Certificateholders do not invest directly in those social purposes nor are payments made to certificateholders derived directly from them. ${ }^{72}$ Instead, the periodic distributions paid to certificateholders are contractually based on commodity murabaha arrangements with no articulated social objective. Despite this contractual separation between certificateholders and Gavi's programmes, IFFIm's primary revenue stream is the scheduled payments due under the Grant Agreements connected directly with those programmes. In practice then, IFFIm's ability to make payments under the commodity murabaha depends on it receiving the scheduled payments related to the funded social programmes. $^{73}$

While the Sukuk IFFIm were not subject to independent verification of their social objectives, both the 2014 and 2015 issues were oversubscribed ${ }^{74}$ and received accolades from the finance industry. ${ }^{75}$ Through the issue of the Sukuk IFFIm, IFFIm has been able to provide Gavi with the immediate upfront capital needed to fund social programmes that are not, in and of themselves, able to generate periodic payments of profit.

\section{Sukuk Ihsan:}

In 2015, Khazanah Nasional Berhad ('Khazanah'), the investment fund of the Government of Malaysia, established a responsible finance sukuk programme with an SPV issuer, Ihsan Sukuk Bhd (the 'Sukuk Ihsan Programme'). ${ }^{76}$ The Sukuk Ihsan Programme was the first approved under the SC's SRI Sukuk Standards, ${ }^{77}$ and since the programme's establishment, there have been two series ${ }^{78}$ of responsible finance sukuk issued under it ${ }^{79}$ (together, the 'Sukuk Ihsan'). The proceeds from the issue of the Sukuk Ihsan were invested in the Yayasan AMIR Trust Schools Programme, a programme run by a non-profit foundation to address the quality of education in government schools in Malaysia. $^{80}$

72 A failure by IFFIm to invest the issue proceeds in socially beneficial programmes will not trigger the early redemption of the Sukuk IFFIm certificates. IFFIm I PPM, Condition 1 Definitions and Interpretation-Definition of 'IFFIm Event' and IFFIm II PPM, Condition 1 Definitions and Interpretation-Definition of 'IFFIm Event'.

73 IFFIm I PPM, 7 and IFFIm II PPM, 7.

74 IFFIm, 'International Finance Facility for Immunisation Issues First Sukuk, Raising US\$500 Million' (IFFIm, 27 November 2014) <https://www.iffim.org/library/news/press-releases/2014/international-finance-facility-for-immunisation-issues-first-sukuk,raising-us\$-500-million/> accessed 30 April 2019 (with respect to the 2014 IFFIm sukuk) IFFIm, 'IFFIm Issues Second Sukuk, Raising US\$200 Million' (IFFIm, 17 September 2015) <https://www.iffim.org/library/news/press-releases/2015/iffim-issues-secondsukuk-raising-usd-200-million/> accessed 30 April 2019 (with respect to the 2015 IFFIm sukuk). The issue of the 2019 IFFIm sukuk to the Islamic Development Bank means that oversubscription is not relevant in the context of that sukuk.

75 The 2014 IFFIm sukuk won 2014 Social Impact Deal of the Year from Islamic Finance News, Best Supranational Sukuk for 2014 from EMEA Finance and the 2015 Innovation in Islamic Finance Award from Euromoney.

76 Khazanah Nasional Berhad, 'Khazanah Issues World's First Ringgit-Denominated Sustainable and Responsible Investment Sukuk' (Media Statement, 4 June 2015) <https://www.khazanah.com.my/Media-Downloads/News-Press-Releases/2015/Khazanahissues-world\%E2\%80\%99s-first-ringgit-denominated> accessed 30 April 2019.

77 Noordin and others (n 6) 416. Prospectus dated 13 July 2017 for the proposed issue by Ihsan Sukuk Berhad of up to RM5.0 million $4.60 \%$ retail sukuk due 2024 ('Series 2 Ihsan Sukuk Prospectus'), s 3.3.

78 For the purposes of this article, I have referred to non-simultaneous issuances of responsible finance sukuk under a programme as 'series' and simultaneous issuances of responsible finance sukuk under a programme or as part of a standalone issuance as 'tranches'.

79 Ihsan Sukuk Berhad issue of RM100,000,000 4.30\% sukuk certificates due 2022 and Ihsan Sukuk Berhad issue of RM100,000,000 4.60\% sukuk certificates due 2024.

80 Series 2 Ihsan Sukuk Prospectus, s 8.1; Ihsan Sukuk Berhad, Information Memorandum dated 11 June 2015 for the proposed issue of RM100.0 million in sukuk ('Series 1 Ihsan Sukuk Information Memorandum'), s 1.4. 
The Sukuk Ihsan Programme is unique amongst responsible finance sukuk issued to date. The contractual structure of both series of Sukuk Ihsan involves wakalah (Islamic agency), commodity murabaha and istithmar (Islamic investment agency) agreements. Under this arrangement, the sukuk trustee (CIMB Islamic Trustee Berhad) acting on behalf of certificateholders entered into a wakalah agreement with the issuer. ${ }^{81}$ The sukuk trustee appointed the issuer as agent (wakeel) with respect to the investment of the issue proceeds from the relevant series of Sukuk Ihsan. ${ }^{82}$ The issuer in turn appointed Khazanah as subagent (the investment wakeel) to invest these issue proceeds on behalf of certificateholders. ${ }^{83}$ The issuer issued the Sukuk Ihsan certificates and declared a trust in favour of certificateholders over the issue proceeds and any assets purchased using those proceeds. ${ }^{84}$ This gives certificateholders an undivided proportionate beneficial ownership interest in the issue proceeds, the purchased assets and, in each case, the rights, title, interest, entitlement and benefit in relation thereto. ${ }^{85} \mathrm{With}$ the issue proceeds, Khazanah (as investment wakeel) purchased shari'ah-compliant tangible assets (unconnected with the funded project) from itself (as seller) ${ }^{86}$ and shari'ah-compliant commodities purchased and sold using a commodity murabaha. ${ }^{87}$ Under this commodity murabaha, Khazanah (as buyer on its own behalf) requested commodities from Khazanah (as investment wakeel on behalf of certificateholders). The investment wakeel purchased the commodities at a price equal to the balance of the issue proceeds remaining after the purchase of the tangible assets. The commodities were sold to Khazanah at their original cost price, plus the aggregate preagreed profit margin to be paid in instalments. ${ }^{88}$ Khazanah immediately on-sold the commodities for cash at their original cost price. ${ }^{89}$ This cash payment, together with the amount paid to Khazanah for the purchase of the tangible assets, provides Khazanah with an amount equal to the Sukuk Ihsan issue proceeds to be used for investment in the Yayasan AMIR Trust Schools Programme. ${ }^{90}$ During the tenor of the relevant series of Sukuk Ihsan,

81 Series 1 Ihsan Sukuk Information Memorandum, s 2.0 item (2)(c)(1) Principal Terms and Conditions of the Sukuk Programme-Facility Description and Series 2 Ihsan Sukuk Prospectus, s 4.1 item (2)(e)(1) Information on the Sukuk Programme and Retail Sukuk Ihsan-Principal Terms and Conditions_Facility Description.

82 Ibid.

83 Ibid.

84 Series 1 Ihsan Sukuk Information Memorandum, s 2.0 item (2)(c)(2) Principal Terms and Conditions of the Sukuk Programme-Facility Description and Series 2 Ihsan Sukuk Prospectus, s 4.1 item (2)(e)(2) Information on the Sukuk Programme and Retail Sukuk Ihsan-Principal Terms and Conditions-Facility Description.

85 This ownership of the underlying issue proceeds and investment assets into which those proceeds have been invested reflects the investment agency aspect of the sukuk. See Series 2 Ihsan Sukuk Prospectus, app 3-Shariah Pronouncements (Pronouncement issued by Amanie Advisors Sdn Bhd) (the Series 1 Ihsan Sukuk Information Memorandum does not set out in full the shari'ah pronouncements).

86 As is the case with sukuk issuances more generally, the issuer and obligor (if applicable) assume multiple roles within most responsible finance sukuk issuances. This reflects the layered contractual structure used to generate periodic distributions and the use of income-generating assets or commodities within those contractual structures.

87 Series 1 Ihsan Sukuk Information Memorandum, s 2.0 item (2)(c)(3) Principal Terms and Conditions of the Sukuk Programme - Facility Description and Series 2 Ihsan Sukuk Prospectus, s 4.1 item (2)(e)(3) Information on the Sukuk Programme and Retail Sukuk Ihsan-Principal Terms and Conditions-Facility Description.

88 Ibid.

89 Ibid.

90 There is a positive covenant imposed on Khazanah to immediately notify the sukuk trustee of any change in the use of proceeds from the Sukuk Khazanah. A failure to give this notification could, however, potentially result in the early redemption of the Sukuk Khazanah certificates, Series 1 Ihsan Sukuk Information Memorandum, s 2 item (w)(ii)_Principal Terms and Conditions 
returns generated by investment in the tangible assets and the commodities up to a preagreed amount form the semi-annual periodic distributions payable to certificateholders. ${ }^{91}$ Any returns generated above the pre-agreed amount are retained by Khazanah as an incentive fee for its work as investment wakeel. $^{92}$

At maturity or early redemption of the Sukuk Ihsan certificates, ${ }^{93}$ Khazanah will purchase the certificateholders' interest in the tangible assets at their market value (or, if these tangible assets are unlisted shares, at a value based on the net tangible assets of the underlying company). ${ }^{94}$ Any outstanding amounts due from Khazanah under the commodity murabaha will also become payable. ${ }^{95}$ These amounts will be used to repay to certificateholders the outstanding principal amount of the relevant series of Sukuk Ihsan, together with accrued but unpaid periodic distributions. Following repayment, the Sukuk Ihsan certificates will be redeemed and cancelled. ${ }^{96}$

It is this amount payable upon redemption of the Sukuk Ihsan certificates that distinguishes the Sukuk Ihsan from other responsible finance sukuk. For each series of Sukuk Ihsan, the parties agreed a series of performance targets. These targets are indicators of the success of the Yayasan AMIR Trust Schools Programme and require teachers, senior management and students in selected schools to achieve pre-agreed benchmarks of competency within a five-year period. ${ }^{97}$ In the event that the key performance indicators are achieved, the principal amount of the relevant series of Sukuk Ihsan will be adjusted downwards by an agreed amount, ${ }^{98}$ and so the amount payable on

of the Sukuk Programme - Covenants and s 4.1 item (2)(mm)(xiii)—Information on the Sukuk Programme and Retail Sukuk IhsanPrincipal Terms and Conditions-Covenants.

91 Series 1 Ihsan Sukuk Information Memorandum, s 2.0 item (2)(c)(4) Principal Terms and Conditions of the Sukuk Programme -Facility Description and Series 2 Ihsan Sukuk Prospectus, s 4.1 item (2)(e)(4) Information on the Sukuk Programme and Retail Sukuk Ihsan-Principal Terms and Conditions_Facility Description.

92 ibid.

93 Following a declaration of a dissolution event (such as non-payment by the issuer of any amount due from it under any of the transaction documents, failure by the issuer to observe or perform its obligations under any of the transaction documents). Series 1 Ihsan Sukuk Information Memorandum, s 2.0 item (2)(v) Principal Terms and Conditions of the Sukuk Programme-Events of Default, Dissolution Event and Enforcement Event, where applicable and Series 2 Ihsan Sukuk Prospectus, s 4.1 item (2)(aa) Information on the Sukuk Programme and Retail Sukuk Ihsan-Principal Terms and Conditions-Events of Default and Enforcement Events, where applicable, including recourse available to investors.

94 Certificateholders agree to waive this payment so that it can be retained by Khazanah as an incentive fee, subject to all amounts payable under the Sukuk Ihsan have been settled. Series 1 Ihsan Sukuk Information Memorandum, s 2.0 item (2)(c)(5) Principal Terms and Conditions of the Sukuk Programme-Facility Description and Series 2 Ihsan Sukuk Prospectus, s 4.1 item (2)(e)(5) Information on the Sukuk Programme and Retail Sukuk Ihsan-Principal Terms and Conditions-Facility Description.

95 Series 1 Ihsan Sukuk Information Memorandum, s 2.0 item (2)(v) Principal Terms and Conditions of the Sukuk ProgrammeEvents of Default, Dissolution Event and Enforcement Event, where applicable and Series 2 Ihsan Sukuk Prospectus, s 4.1 item (2)(aa) Information on the Sukuk Programme and Retail Sukuk Ihsan-Principal Terms and Conditions_Events of Default and Enforcement Events, where applicable, including recourse available to investors.

96 Series 1 Ihsan Sukuk Information Memorandum, s 2.0 item (2)(c)(5) Principal Terms and Conditions of the Sukuk Programme-Facility Description and Series 2 Ihsan Sukuk Prospectus, s 4.1 item (2)(e)(5) Information on the Sukuk Programme and Retail Sukuk Ihsan-Principal Terms and Conditions_Facility Description.

97 Series 1 Ihsan Sukuk Information Memorandum, s 7.4 Yayasan Amir-KPIs for the First Sukuk Ihsan and Evaluation of KPIs and Series 2 Ihsan Sukuk Prospectus, s 8.4 Information about Yayasan Amir-KPIs for the Retail Sukuk Ihsan Eligible SRI Project and Evaluation of KPIs. These requirements are as follows: within a five-year period, at least 20 schools are selected for participation in the programme, at least $50 \%$ of teachers in the selected schools achieve a specified benchmark of pedagogical proficiency, at least $50 \%$ of senior management in the selected schools achieve a specified benchmark of proficiency in certain leadership functions and at least $50 \%$ of students in the selected schools demonstrate prescribed competencies, values and attitudes.

98 This adjustment was set at a reduction of $6.22 \%$ of the principal amount of the Series 1 Sukuk Khazanah and a reduction of $3.18 \%$ of the principal amount of the Series 2 Sukuk Khazanah. 
redemption of the Sukuk Ihsan certificates will be reduced. ${ }^{99}$ In the event the key performance indicators are not met, the principal amount, together with accrued but unpaid periodic distributions, will be paid in full. ${ }^{100}$ Representing a financial penalty for attaining prescribed targets, this step-down returns mechanism was described by Khazanah as part of certificateholders' 'social obligation in recognizing the positive impact $^{\prime 101}$ of the funded programme. As a result, while the certificateholders do not invest directly in the Yayasan AMIR Trust Schools Programme, and their returns are derived from income generated by assets that are unconnected with that programme, payments to certificateholders on redemption of the sukuk certificates will reflect the programme's performance.

As required by the SC's SRI Sukuk Standards, the issuer confirms in the Sukuk Ihsan offering documents that it has and will continue to comply with applicable environmental, social, governance and recognized best practice standards. ${ }^{102}$ It also undertakes to report annually to certificateholders on the use of proceeds and, to the extent possible, the attainment of the funded programme's impact objectives. ${ }^{103}$ The offering documents do not explicitly set out what these impact objectives are, although they do detail the key performance indicators to be achieved. While no external assessment of the social purposes of the Yayasan AMIR Trust Schools Programme was included in the Sukuk Ihsan offering documents, an independent auditors' report to be delivered prior to maturity of each series of Sukuk Ihsan will confirm whether the key performance indicators have been met. ${ }^{104}$

The returns structure of the Sukuk Ihsan distinguishes these certificates from social impact bonds (which reward attainment of key performance indicators) and social bonds (which pay agreed returns notwithstanding the performance of the funded project). They are, therefore, '[n] ot your typical SRI', ${ }^{105}$ something that commentators noted could impact the popularity of the Sukuk Ihsan amongst investors. ${ }^{106}$ While two series of sukuk

99 Christina Khouri, 'Khazanah Ahead of its Time with SRI sukuk' (9 June 2015) Global Capital Asia <https://www. globalcapital.com/article/rxzbdhts08qw/khazanah-ahead-of-its-time-with-sri-sukuk> accessed 30 April 2019.

100 Khazanah Nasional Berhad (n 76). As noted by RAM Ratings in the context of its rating of the Ihsan SRI Sukuk Programme, 'the repayment of the Sukuk Ihsan will depend on the eligible SRI project's ability to meet identified key performance indicators'. RAM Ratings, 'RAM Ratings Assigns AAA(s) Preliminary Rating to Malaysia's First SRI Sukuk Programme' (23 April 2015).

101 Khazanah Nasional Berhad (n 76).

102 Series 1 Ihsan Sukuk Information Memorandum, s 4.5 The Issuer-Compliance statement from the Issuer, Series 2 Ihsan Sukuk Prospectus, s 8 Information about Yayasan Amir.

103 Series 1 Ihsan Sukuk Information Memorandum, s 2 item (w)(i) Principal Terms and Conditions of the Sukuk ProgrammeCovenants and Series 2 Ihsan Sukuk Prospectus, s 4.1 item (2)( $\mathrm{mm})$ (xiii) Information on the Sukuk Programme and Retail Sukuk Ihsan-Principal Terms and Conditions-Covenants. See an example of the programme's annual progress report: Yayasan Amir Trust Schools Programme, Annual Progress Report 2017 <https://www.khazanah.com.my/getmedia/318f7323-8222-4844-927e8ac6a6c089b3/2017-YA_AnnualReport.aspx> accessed 30 April 2019.

104 Series 1 Ihsan Sukuk Information Memorandum, s 2.0 item (2)(y)(vii) Principal Terms and Conditions of the Sukuk Programme-Key Performance Indicators ('KPIs') and Series 2 Ihsan Sukuk Prospectus, s 4.1 item (2)(mm)(vii) Information on the Sukuk Programme and Retail Sukuk Ihsan-Principal Terms and Conditions_Key Performance Indicators ('KPIs'). Should the sukuk be redeemed early and prior to this report being made available, the key performance indicators will be deemed not to have been met.

105 Khouri (n 99).

106 Ibid. 
were issued under the Sukuk Ihsan Programme, the programme's structure has not been replicated in subsequent responsible finance sukuk issuances. Instead, the economic substance of subsequent issues has aligned more closely with that of typical responsible finance bonds.

\section{Green and sustainability sukuk}

In 2012, two green sukuk issuances were announced. The first, the Orasis Sukuk, was marketed as the first French green sukuk issuance. ${ }^{107}$ The proceeds from the issue of the Orasis Sukuk were to be invested in solar energy production assets through a joint venture and ijarah (Islamic lease) structure. ${ }^{108}$ However, limited records exist for these instruments or the continued operation of the entities that marketed them. ${ }^{109}$ Green sukuk were also to be issued by SGI-Mitabu, a joint venture between two Australian solar companies. The proceeds of these green sukuk certificates were to be used to fund the first phase of an Indonesian solar project through an istisna' (Islamic construction) structure (during construction of the project) and ijarah and musharaka (Islamic partnership) structures (for the post-completion period). ${ }^{110}$ Initially publicized in 2012, this issuance was considered again in 2015. ${ }^{111}$ The limited documentation available suggests, however, that these sukuk certificates never came to market. ${ }^{112}$

Notwithstanding these initially unsteady steps in the market, 2017, 2018 and 2019 saw the successful issue of several green or sustainability sukuk. The ultimate use of proceeds from these sukuk issuances has largely focused on environmentally beneficial projects, particular solar energy, although broader sustainability benefits were also highlighted in the projects funded by the Sukuk PNBMV and the HSBC Amanah Sustainability Sukuk (each defined below). While most of these sukuk have been issued by Malaysian corporates and marketed to domestic Malaysian investors, the green sukuk issued by the Republic of Indonesia were marketed to international investors as the first sovereign green sukuk issuance.

107 The Orasis Sukuk was marketed by Global Patrimoine Investissement (operating as Legendre Patrimoine) and Hassoune Conseil: Global Patrimoine Investissement and Hassoune Conseil, 'Orasis: First French Sukuk' (Orasis Sukuk, October 2012) Orasis Sukuk Investor Presentation, 1 <https://cenf.univ-paris1.fr/fileadmin/Chaire_CENF/HC_-_Orasis_Sukuk_presentation_10-2012. pdf $>$ accessed 30 April 2019.

108 Ibid 7, Salina Kassim and Adam Abdullah, 'Pushing the Frontiers of Islamic Finance Through Socially Repsonsible Investment Sukuk' [2017] Al-Shajarah 187, 206.

109 Hassoune Conseil's company licence appears to have been cancelled on 4 June 2015. In 2016, the Autorité des Marchés Financiers (AMF) in France fined Legendre Patrimoine $€ 500,000$ and prohibited it from carrying out activities as a financial investment advisor for a period of three years due, among other things, to Legendre's failure to fulfil its obligation to communicate accurate, clear and not misleading information with respect to yield on its green investment products. AMF La Commission des Sanctions, 7 June 2016, 'Decision de la Commission des Sanctions à l'égard des Societes Global Patrimoine Investissement, Kalys Investissements et de M. Louis Sanguinetti' Référence: SAN-2016-07.

110 Jonathan Lawrence and Rebecca Clow, 'Solar Sukuk Lights the Way to Alternative Funding Sources: Australia, Indonesia and Malaysia Working Together’ (KeLL Gates Legal Insights, 17 March 2015) $1<$ https://www.klgates.com/solar-sukuk-lights-the-wayto-alternative-funding-sources-australia-indonesia-and-malaysia-working-together-03-12-2015/> accessed 30 April 2019.

111 Ibid.

112 Asian Development Bank, Promoting Green Local Currency Bonds for Infrastructure Development in ASEAN+3 (Asian Development Bank, 2018) 26 <https://www.adb.org/sites/default/files/publication/410326/green-lcy-bonds-infrastructure-development-asean3.pdf $>$ accessed 30 April 2019. 


\section{Sukuk Tadau:}

In July 2017, Tadau Energy Sdn Bhd ('Tadau'), a Malaysian company operating in the electricity sector, issued RM250,000,000 (approximately USD63,000,000) worth of green sukuk (the 'Sukuk Tadau') pursuant to an Islamic medium term note programme (the 'Sukuk Tadau Programme'). 113

The proceeds from the issue of each tranche of Sukuk Tadau have been used for shari'ah-compliant purposes involving the financing, construction and operation of two solar photovoltaic plants and associated facilities in Malaysia (the 'Sukuk Tadau Assets'). ${ }^{114}$ Investment of these issue proceeds and generation of income for certificateholders are based on a combination of istisna' and ijarah agreements. Following issue of the Sukuk Tadau, the sukuk trustee (Malaysian Trustees Berhad) declared a trust in favour of certificateholders over assets comprising rights, interest and benefit in, to and under the completed Sukuk Tadau Assets and related transaction documents. ${ }^{115}$ This gives certificateholders an undivided proportionate beneficial ownership interest in the completed Sukuk Tadau Assets themselves. ${ }^{116}$ Pursuant to an istisna' agreement, the sukuk trustee paid the issuer (as contractor) an amount equal to the issue proceeds to build, construct and deliver the Sukuk Tadau Assets. ${ }^{117}$ This amount is payable in instalments during the construction phase of each Sukuk Tadau Asset. ${ }^{118}$ Using funds received from the istisna' agreement, the issuer in turn entered into a parallel engineering, procurement and construction (EPC) arrangement with a contractor to procure the required building, construction and delivery of the Sukuk Tadau Assets. ${ }^{119}$ To provide certificateholders with periodic distributions during the tenor of the Sukuk Tadau, the sukuk trustee agreed to lease each (as yet uncompleted) Sukuk Tadau Asset to the issuer during that asset's construction phase in exchange for payment of predetermined advance rental. ${ }^{120}$ From the point of completion and delivery of the Sukuk Tadau Assets to the maturity date of the last outstanding tranche of Sukuk Tadau, the sukuk trustee will then lease each completed Sukuk Tadau Asset to the issuer for a predetermined rental. ${ }^{121}$ Both forms of rental payment will be equal in size and timing to

113 The Sukuk Tadau were issued in 15 tranches with maturities of between 2 and 16 years.

114 Tadau Energy Sdn Bhd, Information Memorandum dated 16 June 2017 for the 'proposed issue of Islamic medium term notes pursuant to an Islamic medium term notes programme under the shari'ah principles of istisna' and ijarah of up to RM250,000,000 in nominal value', as supplemented by a Supplementary Information Memorandum dated 31 July 2017 ('Tadau Information Memorandum'), s 4.1.1 Project Information-Description of the Solar PV Plant.

115 Ibid, s 5 Principal Terms and Conditions of the Sukuk Programme-Facility description. Trust Deed dated 19 June 2017 between Tadau Energy Sdn Bhd and Malaysian Trustees Berhad.

116 Tadau Information Memorandum, s 5 Principal Terms and Conditions of the Sukuk Programme-Facility Description; cl 2.1 Trust Deed dated 19 June 2017 between Tadau Energy Sdn Bhd and Malaysian Trustees Berhad, cl 3.1.

117 Tadau Information Memorandum, s 5 Principal Terms and Conditions of the Sukuk Programme-Facility Description.

118 Ibid.

119 Pending utilization of the sukuk issuance proceeds as provided for in the documents, these proceeds may be invested in Shari'ah-compliant investment products approved by the Shari'ah Advisory Council of SC, the Shari'ah Advisory Council of Bank Negara Malaysia and/or other recognized Shari'ah authorities, ibid, s 5 Principal Terms and Conditions of the Sukuk ProgrammePermitted Investments, if applicable.

120 Ibid, s 5 Principal Terms and Conditions of the Sukuk Programme-Facility Description.

121 Ibid. 
the periodic distributions due to certificateholders. The issuer will also be appointed as servicing agent to perform ownership-related obligations and to pay ownership expenses in relation to the Sukuk Tadau Assets. ${ }^{122}$

Should a Sukuk Tadau Asset not be completed and delivered, or should a dissolution event ${ }^{123}$ be declared prior to completion and delivery, the issuer will refund to the sukuk trustee the istisna' price, together with compensation amounting to the periodic distributions already paid and any accrued but unpaid periodic distributions due. ${ }^{124}$ The sukuk trustee will repay any advance rentals paid. ${ }^{125}$ Should a dissolution event be declared following completion and delivery, the issuer will purchase the relevant Sukuk Tadau Asset pursuant to a purchase undertaking. The price payable will equal the original istisna' price for that Sukuk Tadau Asset, together with any ownership expenses and all accrued but unpaid periodic distributions. ${ }^{126}$ The Sukuk Tadau certificates will then be redeemed and cancelled. ${ }^{127}$ At maturity of each tranche of Sukuk Tadau, the final rental payment made by the issuer will consist of the last periodic distribution, the outstanding principal amount of the maturing tranche and any ownership expenses (which will be setoff against a reimbursement of ownership expenses paid to the issuer as servicing agent). ${ }^{128}$ This final lease payment will be sufficient to repay to certificateholders their capital and any accrued but unpaid periodic distributions. Certificateholders of a maturing tranche of Sukuk Tadau will then transfer by way of gift their proportionate ownership interest in the relevant Sukuk Tadau Asset to certificateholders of any outstanding Sukuk Tadau. ${ }^{129}$ Once all tranches of Sukuk Tadau have matured, the Sukuk Tadau Assets will be transferred to the issuer by way of gift. ${ }^{130}$

The Sukuk Tadau were the first green sukuk to be issued under the SC's SRI Sukuk Standards. ${ }^{131}$ As required by these standards, the Sukuk Tadau Programme offering document confirms the impact objectives of the Sukuk Tadau Assets as being to 'conserve the environment by providing an environmentally friendly, clean and sustainable power

122 Ibid

123 Such as non-payment of any amount due under the Sukuk Tadau by the issuer, misrepresentation, or the winding-up, dissolution or liquidation of the issuer, ibid, s 5 Principal Terms and Conditions of the Sukuk Programme-Events of Default or Enforcement Events, where applicable, including recourse available to investors. It is a dissolution event if various stages of the Sukuk Tadau Assets are not completed.

124 Ibid, s 5 Principal Terms and Conditions of the Sukuk Programme-Facility Description.

125 This amount will be set-off against the compensation amount.

126 In addition to the issuer's obligations upon the occurrence of a dissolution event, Kagayaki Energy Sdn Bhd (a shareholder of the issuer), acting as sponsor, will provide an unconditional and irrevocable letter of undertaking for the period from the issue date of the SRI Sukuk Tadau to the date, that is, six months from the commercial operation date of the second Sukuk Tadau Asset to inject equity into the project and to fund cost overruns. ibid, s 5, Principal Terms and Conditions of the Sukuk Programme-Sponsor Completion Support.

127 Redemption and cancellation of the Sukuk Tadau will also occur upon a total loss of a Sukuk Tadau Asset with the insurance proceeds being used to pay the outstanding principal amount of the Sukuk Tadau plus any accrued but unpaid periodic distributions. ibid, s 5, Principal Terms and Conditions of the Sukuk Programme-Facility Description.

128 Ibid.

129 Ibid.

130 Ibid.

131 Affin Hwang Capital, 'Tadau Energy Sdn Bhd Issues RM250 Million Sri Sukuk; the First Green Sukuk in Malaysia' (Press Release, 27 July 2017) <https://affinhwang.com/press-releases/tadau-energy-sdn-bhd-issues-rm250-million-sri-sukuk-the-firstgreen-sukuk-in-malaysia/> accessed 30 April 2019. 
supply and [to be] part of creating a sustainable world'. ${ }^{132}$ The issuer also provides confirmation that it has and will continue to comply with relevant environmental, social, governance and best practice standards relating to the Sukuk Tadau Assets ${ }^{133}$ and covenants to periodically report to certificateholders on the use of proceeds and attainment of the outlined impact objectives. ${ }^{134}$ Notwithstanding this clear attempt by the issuer to adhere to the SC's SRI Sukuk Standards, the commissioned independent assessment (in the form of a second opinion) given by the Center for International Climate Research (CICERO) addressed the adherence of the issuer's Green Sukuk Framework to ICMA's GBPs, rather than to the SC's SRI Sukuk Standards. ${ }^{135}$ CICERO rated the Green Sukuk Framework 'Dark Green' meaning that the funded project represented a realization of the 'long-term vision of a low carbon and climate resilient future'. ${ }^{136}$ However, CICERO highlighted shortcomings in the transparency and reporting commitments of the issuer, a lack of substantial environmental policies for the issuer's operations, and potential controversy with respect to land-use and local environmental impact of renewable energy power plants. ${ }^{137}$

The Sukuk Tadau were oversubscribed ${ }^{138}$ and reflect the fact that approval under the SC's SRI Sukuk Standards will not prevent an issuance from also being assessed against market-based international green bond standards. ${ }^{139}$ Unlike the majority of other responsible finance sukuk, the Sukuk Tadau certificateholders received proportionate ownership interest in the funded project. As a result, although supported by credit enhancements to ensure payment of periodic distributions and return of capital on redemption, the returns paid to certificateholders are derived from that funded project. ${ }^{140}$ In this way, the Sukuk Tadau connect certificateholders directly to a green project.

\section{Sukuk QSP:}

Within days of the establishment of the Sukuk Tadau Programme, Quantum Solar Park (Semenanjung) Sdn Bhd (QSP) a Malaysian company carrying out solar power generation and related activities, ${ }^{141}$ published an offering document (as supplemented,

\footnotetext{
132 Tadau Information Memorandum, s 7.4, Industry Overview-Eligible SRI Project.

133 Ibid.

134 Ibid, s 5, Principal Terms and Conditions of the Sukuk Programme-Information Covenants.

135 Center for International Climate Research, “"Second Opinion” on Tadau Energy's Green Sukuk Framework' (24 July 2017 ) 6 $<\mathrm{http}$ //tadau.com.my/second-opinion-on-tadau-energy-green-sukuk-framework-final24072017.pdf> accessed 30 April. This Second Opinion was not originally annexed to the Tadau Information Memorandum dated 16 June 2017 but was subsequently appended as a new app 6 as a result of the Supplemental Information Memorandum dated 31 July 2017.

136 Ibid 5.

137 Ibid 12.

138 Environmental Finance, 'Tadau Energy’s RM250 million ( $\$ 59$ million) sukuk was the first to be labelled green’ (28 March 2018) <https://www.environmental-finance.com/content/awards/green-bond-awards-2018/winners/award-for-innovation-bond-structure-tadau-energy.html> accessed 30 April 2019.

139 The complementarity between ICMA's GBPs and the SC's SRI Sukuk Standards was also noted by the World Bank in its case study of Malaysia in The World Bank, 'Helping Malaysia Develop the Green Sukuk Market' (2017), $2<\mathrm{http}: / /$ pubdocs.worldbank. org/en/514801523545420821/case-study-financial-products-malaysia-2018-GreenSukukMarketDevelopment.pdf> accessed 30 April 2019.

140 Trust Deed dated 19 June 2017 between Tadau Energy Sdn Bhd and Malaysian Trustees Berhad, cl 3.1.

141 QSP Information Memorandum (defined below), s 3.2.
} 
the 'QSP Information Memorandum') ${ }^{142}$ for a standalone issue of green sukuk. In October 2017, RM1,000,000,000 (approximately USD250,000,000) worth of sukuk certificates were issued pursuant to this QSP Information Memorandum (the 'Sukuk QSP') ${ }^{143}$ to fund the construction and operation of three solar photovoltaic plants located in Malaysia (the 'Sukuk QSP Assets'). ${ }^{144}$

The structure of the Sukuk QSP is based on a commodity murabaha, while the issuer invested the issue proceeds in the Sukuk QSP Assets through a separate intercompany financing arrangement. Under the commodity murabaha structure, the sukuk trustee (Pacific Trustees Berhad) appointed the issuer as agent with respect to the purchase and sale of commodities. ${ }^{145}$ The issuer then appointed the sukuk trustee as subagent for this same purchase and sale. ${ }^{146}$ The sukuk trustee (acting as subagent) purchased commodities for cash at a price equal to the Sukuk QSP issue proceeds. ${ }^{147}$ This price was paid by the issuer (as agent for the certificateholders) ${ }^{148}$ giving certificateholders an undivided proportionate ownership interest in the purchased commodities (but not the Sukuk QSP Assets). ${ }^{149}$ The sukuk trustee then sold the commodities to the issuer at a price equal to their original cost price, plus the aggregate pre-agreed profit margin for the relevant tranche of Sukuk QSP. ${ }^{150}$ This cost price-plus-profit is payable on a deferred basis, with the profit element payable in instalments and then used to pay periodic distributions to certificateholders. ${ }^{151}$ Following their sale, the commodities were immediately on-sold on behalf of the issuer for cash at their original cost price. ${ }^{152}$

Prior to the issue of the Sukuk QSP certificates, project companies for each of the Sukuk QSP Assets (the 'Project Companies') entered into power purchase agreements with Tenaga Nasional Berhad (TNB) (a public energy company). ${ }^{153}$ Pursuant to these power purchase agreements, the Project Companies agreed to design, construct, own, operate and maintain the Sukuk QSP Assets and TNB agreed to purchase the generated electrical output. ${ }^{154}$ Project development costs with respect to these Sukuk QSP Assets

142 Quantum Solar Park (Semenanjung) Sdn Bhd Information Memorandum dated 19 June 2017 for the 'proposed issue or offer for subscription or purchase of or invitation to subscribe for or purchase of sukuk based on the shariah principle of murabaha (via a tawarruq arrangement) of up to RM1,000,000,000 in principal amount', as supplemented by a Supplementary Information Memorandum dated 8 September 2017.

143 The Sukuk QSP was issued in 33 tranches with maturities of between 2 and 18 years.

144 QSP Information Memorandum, s 7.2.1 Information on the Projects_Technical Description.

145 Ibid, s 2.1, item (4) Principal Terms and Conditions-Facility Description.

146 Ibid.

147 Ibid.

148 Ibid.

149 Ibid. Trust Deed dated 3 August 2017 between Quantum Solar Park (Semenanjung) Sdn Bhd and Pacific Trustees Berhad, cl 3.2 .

150 QSP Information Memorandum, s 2.1, item (4) Principal Terms and Conditions-Facility Description. If the Sukuk QSP are being sold at a discount, the sales price will include the discounted amount, which is the difference between the principal amount of the Sukuk QSP and the original purchase price of the commodities.

151 Ibid, s 2.1, item (4) Principal Terms and Conditions-Facility Description.

152 Ibid.

153 Ibid, s 7.6.1, Information on the Projects-Summary of Key Project Documents.

154 Ibid. In January 2019, the Malaysian Rating Corporation downgraded the Sukuk QSP's rating following a delay in the completion of the Sukuk QSP Assets, Malaysian Rating Corporation Berhad, 'MARC Extends MARCWatch Negative on QSP 
were partially funded by QSP through intercompany finance agreements. ${ }^{155}$ In order to provide this funding on an intercompany basis, QSP advanced an amount equivalent to the Sukuk QSP issue proceeds that it received following on-sale of the commodities from the commodity murabaha arrangement. ${ }^{156}$ Once the Sukuk QSP Assets are constructed, the Project Companies will use revenue generated by these assets to make periodic payments to QSP under the intercompany finance agreements. ${ }^{157}$

At maturity of the Sukuk QSP or upon the declaration of a dissolution event, ${ }^{158}$ the full cost price-plus-profit due under the commodity murabaha becomes payable by the issuer, less amounts already paid. ${ }^{159}$ To ensure that the issuer is in a position to make this payment, the Project Companies unconditionally and irrevocably guaranteed to pay the outstanding principal amount of the Sukuk QSP certificates and any accrued but unpaid periodic distributions upon a declaration of a dissolution event. ${ }^{160}$ Repayment of the principal due from the Project Companies under the intercompany finance agreements will also align with the maturity dates of the Sukuk QSP. ${ }^{161}$ Once all amounts due to certificateholders have been paid, the Sukuk QSP certificates will be redeemed and cancelled. ${ }^{162}$

Unlike the Sukuk Tadau, then, where the certificateholders have an ownership interest in the funded project and returns paid to certificateholders are generated by that project, the Sukuk QSP certificateholders have an ownership interest in commodities being bought and sold. The funding of the Sukuk QSP Assets arises contractually from the intercompany finance agreements to which certificateholders are not a party. Certificateholders are instead granted security in the form of charges over each Project Company's (and the issuer's) rights, interests, titles and benefits under the project documents, certain specified accounts and all present and future assets of each Project Company and the issuer. ${ }^{163}$ Nevertheless, the QSP Information Memorandum acknowledges that capital paid by the Project Companies pursuant to the intercompany finance

Semenanjung's RM1.0 Billion Green SRI Sukuk Rating' (MARC, 24 April 2019) <https://www.marconline.com.my/press/5927> accessed 30 April 2019.

155 Ibid, s 7.4.2, Information on the Projects_Projects' Capital Structure. In addition to financing raised through the issue of the Sukuk QSP, at least $20 \%$ of the total project costs will come from an injection of equity into the Project Companies to occur on or before the date when any of the Project Companies have paid $90 \%$ of the costs and expenses payable under the relevant EPC contract or the balance of any Project Company capital account falls to RM10,000,000. Equity injections and/or subordinated financings may also be provided in the event of a cost overrun or with respect to certain costs and expenses relating to the QSP Sukuk Assets.

156 Ibid, s 2.1, item (4) Principal Terms and Conditions-Facility Description.

157 Ibid, s 8.2.1, Investment Considerations—Risks Relating to the Issuer-Issuer's Ability to Meet its Obligations under the Green SRI Sukuk.

158 Referred to in the QSP Information Memorandum as an event of default, ibid, s 2.1, item (26) Principal Terms and Conditions-Events of Default or Enforcement Events, where applicable, including recourse available to investors. While not a dissolution event to fail to direct the issue proceeds towards the funded projects, the issuer covenants not to change the use of proceeds of the Sukuk QSP, s 2.1, item (19) Principal Terms and Conditions-Negative Covenants.

159 ibid, s 2.1, item (4) Principal Terms and Conditions_Facility Description.

160 Ibid.

161 Ibid, app 2-viii.

162 Ibid, s 7.6.2, Information on the Projects-Summary of Key Project Documents.

163 QSP Information Memorandum, s 2.1, item (12) Principal Terms and Conditions-Details of Security/Collateral Pledged, if applicable. 
agreements will be used by the issuer to fund payments due under the Sukuk QSP certificates. ${ }^{164}$ As is the case for the Sukuk IFFIm, while there is a contractual separation between the certificateholders and the funded project, that project ultimately provides a revenue stream that is used to pay certificateholders. Reflecting this, the 2019 delay in the completion of the Sukuk QSP Assets resulted in the issuer having to top up the fund out of which periodic distributions are to be paid. ${ }^{165}$

As required by the SC's SRI Sukuk Standards, the QSP Information Memorandum confirms that QSP has and will continue to comply with applicable standards relating to the QSP Sukuk Assets ${ }^{166}$ and that it will periodically report to certificateholders on use of the issue proceeds. ${ }^{167}$ It also outlines the impact objectives to be achieved from the Sukuk QSP Assets as being the facilitation and promotion of sustainable and responsible investments in Malaysia, supporting Malaysia with respect to reaching its solar power targets, and contributing to the sustainable electricity supply and reduction of carbon emissions in Malaysia. ${ }^{168}$ These impact objectives are more closely tied to Malaysian government policies than those articulated in the Sukuk Tadau Programme. CICERO provided the independent assessment of QSP's Green Bonds Framework, classifying it as 'Dark Green'. ${ }^{169}$ In doing so, CICERO noted the potential for a funded project to impact on the broader community in a way that may or may not be climate friendly. ${ }^{170}$

\section{Sukuk PNBMV:}

In December 2017, PNB Merdeka Ventures Sdn Berhad (PNBMV) issued RM690,000,000 (approximately USD170,000,000) worth of sukuk certificates (the 'Sukuk PNBMV') under its Islamic medium term note programme (the 'Sukuk PNBMV Programme'). ${ }^{171}$

PNBMV, whose principal activities involve management and development of land, is a wholly owned subsidiary of Permodalan Nasional Berhad (PNB), ${ }^{172}$ a fund management company. ${ }^{173}$ Unlike other Malaysian entities that have issued, or acted as obligor for an issue of, green sukuk, the principal activities of PNBMV and PNB are not environmentally focused. Reflecting this, the proceeds from the issue of the Sukuk PNBMV were used to partly fund costs relating to the development and construction of 83 storeys of offices

\footnotetext{
164 Ibid, s 8.2.1, Investment Considerations-Risks Relating to the Issuer-Issuer's Ability to Meet Its Obligations under the Green SRI Sukuk, which notes that the issuer will only be able to meet its obligations to certificateholders and pay amounts due under the Sukuk QSP from 'the repayment of the Project Companies under the Interco Financing Documents. The Project Companies will be depending on their income and revenue generated under the Projects [that is, the Sukuk QSP Assets] and in particular, the strength of their operation of the Projects to generate positive cashflow.'

165 Malaysian Rating Corporation Berhad, 'MARC Downgrades QSP Semenanjung's RM1.0 Billion Green SRI Sukuk Rating to A+Is and Places Rating on MARCWatch Negative' (MARC, 25 January 2019) <https://www.marconline.com.my/press/5864> accessed 30 April 2019.

166 Ibid, s 1.8, Executive Summary-Eligible SRI Project.

167 Ibid, s 2, item (21), item (n) Principal Terms and Conditions-Information Covenants.

168 Ibid, s 1.8, Executive Summary-Eligible SRI Project.

169 Center for International Climate Research, “'SecondOpinion” on Quantum Solar Park's Green Bonds Framework' (2 June 2017) 6 <https://cicero.oslo.no/file/1238/QSP_2018.pdf> accessed 30 April 2019.

170 Ibid 10.

171 The Sukuk PNBMV were issued over five tranches with maturities of between 5 and 15 years.

172 Sukuk PNBMV Programme, Principal Terms and Conditions, item (A)(8) Corporate Information of Issuer-Principal Activities.

173 Ibid, item (B)(8) Corporate Information of Corporate Guarantor-Principal Activities.
} 
and related infrastructure (the 'Office Tower') within the multi-use Merdeka PNB118 Tower in Malaysia. ${ }^{174}$ Concurrently with the issue of the Sukuk PNBMV, PNBMV issued non-green sukuk certificates to part finance not only the Office Tower but also the broader development project in which the Office Tower will be situated (the project, including the Office Tower, the 'PNBMV Project'). ${ }^{175}$ The Office Tower was deemed by the issuer to be both an eligible project under the SC's SRI Sukuk Standards (as a sustainable building project) and as an eligible green project under the ASEAN Green Bond standards. ${ }^{176}$ PNB also confirmed that the Merdeka PNB118 Tower will have sustainability and social benefits. ${ }^{177}$

The contractual structure underpinning the Sukuk PNBMV is a wakalah and commodity murabaha arrangement. ${ }^{178}$ The lead manager (MIDF Amanah Investment Bank Berhad) acting as facility agent and the certificateholders (acting through the sukuk trustee, AmanahRaya Trustees Berhad) entered into a wakalah agreement. Pursuant to this agreement, the facility agent was appointed as agent for the certificateholders for the purchase and sale of commodities. ${ }^{179}$ At the same time, pursuant to a commodity murabaha agreement, the facility agent purchased commodities for cash at a price equal to the Sukuk PNBMV issue proceeds. These commodities were sold to the issuer at their original cost, plus the pre-agreed profit margin for each tranche of Sukuk PNBMV, payable on a deferred basis. ${ }^{180}$ By subscribing for the Sukuk PNBMV, certificateholders receive an entitlement to this payment, with the pre-agreed profit element payable semiannually. ${ }^{181}$ The commodities were then on-sold for cash at their original cost price. ${ }^{182}$ The issuer used this cash to partly fund the construction and development costs of the Office Tower, as well as to fund the periodic distributions due to certificateholders during the construction phase of the Office Tower. ${ }^{183}$ As was the case for the Sukuk IFFIm, Sukuk Ihsan and Sukuk QSP, returns paid to the Sukuk PNBMV certificateholders are generated through the commodity murabaha arrangement and certificateholders receive no ownership interest in the funded project. Instead, the Sukuk PNBMV are secured by a

174 Sukuk PNBMV Programme, Other Terms and Conditions, item (d) Details on the Utilisation of Proceeds.

175 PNBMV, RM1,184,000,000 5.680\% Sukuk due 2032 issued under a RM3,650,000,000 Sukuk programme, Other Terms and Conditions, item (d) Details on the Utilisation of Proceeds.

176 Sukuk PNBMV Programme, Other Terms and Conditions, Definitions 'Eligible SRI Project'.

177 PNB Merdeka Ventures Sdn Berhad, 'Green Sukuk Framework' (December 2017) para 2 <www.pnbmerdekaventures.com. my/pdf/PNB_Green\%20Sukuk\%20Framework_122017\%20.pdf > accessed 30 April 2019.

178 Sukuk PNBMV Programme, Principal Terms and Conditions, item (D)(3) Details of Facility/Programme-Shariah Principles (for Sukuk).

179 Ibid, item (D)(4) Details of Facility/Programme-Facility Description.

180 Ibid.

181 Ibid. Sukuk PNBMV Programme, Other Terms and Conditions, item (e) Profit/Coupon Rate and (f)—Profit/Coupon Payment Frequency.

182 Sukuk PNBMV Programme, Principal Terms and Conditions, item (D)(4) Details of Facility/Programme—Facility Description.

183 Ibid, item (D)(22) Details of Facility/Programme—Details of Designated Account(s). 
security package that includes security with respect of the Office Tower ${ }^{184}$ and shared security (with PNBMV's non-green sukuk) over assets relating to the PNBMV Project more generally. ${ }^{185}$ This shared security includes a completion guarantee under which PNB unconditionally and irrevocably guarantees to complete the PNBMV Project by a specified date. ${ }^{186}$ Once constructed and delivered to PNBMV, the Office Tower will be leased to PNB on a renewable 15-year term. Returns generated from this lease will fund periodic distributions to certificateholders under the Sukuk PNBMV. ${ }^{187}$

At maturity or early redemption ${ }^{188}$ of the Sukuk PNBMV certificates, all amounts due under the commodity murabaha will become payable by the issuer. ${ }^{189}$ This amount will be used to repay the aggregate outstanding principal amount of the Sukuk PNBMV, together with accrued but unpaid periodic distributions. ${ }^{190}$ The relevant tranche of Sukuk PNBMV will then be redeemed and cancelled. ${ }^{191}$

The Sukuk PNBMV Programme is structured to align with both the SC's SRI Sukuk Standards and the ASEAN Green Bond Standards. Reflecting this, the terms and conditions of the Sukuk PNBMV impose a positive covenant on the issuer to comply 'at all times' during Sukuk PNBMV Programme with the ASEAN Green Bond Standards and the SC's SRI Sukuk Standards. ${ }^{192}$ As required by the ASEAN Green Bond Standards, the Sukuk PNBMV Programme terms and conditions set out how the issue proceeds will be used and managed. ${ }^{193}$ The issuer also undertakes to report annually on the use of those issue proceeds. ${ }^{194}$ However, while the issuer's Green Sukuk Framework confirms the sustainability features and broader social and environmental benefits of the Merdeka PNB118 Tower, ${ }^{195}$ it does not outline these features for the Office Tower specifically.

184 Ibid, item (D)(15) Details of Facility/Programme-Details of Security/Collateral Pledged. This includes security over the strata title in respect of the Office Tower, the Office Tower lease and proceeds, insurance or takaful (Islamic insurance) policies taken out with respect to the Office Tower, certain specified accounts, a first ranking fixed and floating charge over the present and future assets of the issuer and assignment of present and future rights, titles, benefits and interests in documents relating to the management and project documents for the Office Tower.

185 Ibid, item (D)(15) Details of Facility/Programme - Details of Security/Collateral Pledged. This shared security includes charges over land, as well as stratum and subterranean titles to land to be used for the PNBMV Project, the assignment of construction contracts in relation to the PNBMV Project and a completion guarantee given by PNB in relation to the PNBMV ASEAN Sukuk Programme and the PNBMV non-green Sukuk programme.

186 Ibid.

187 Sukuk PNBMV Programme, Other Terms and Conditions, Definition of 'MLA'.

188 Either at the instigation of the issuer or upon a declaration of a dissolution event (referred to in the Sukuk PNBMV Programme as an event of default), which includes a breach, omission or failure to observe or perform a covenant. Sukuk PNBMV Programme, Principal Terms and Conditions, item (D)(26) Details of Facility/Programme-Events of Default or Enforcement Events, where applicable, including recourse available to investors and Sukuk PNBMV Programme, Principal Terms and Conditions, item (D) (29) Details of Facility/Programme-Provisions on Early Redemption. It is a dissolution event if any of the project companies fails to carry out the PNBMV Project.

189 Ibid, item (D)(4) Details of Facility/Programme-Facility Description. Principal Terms and Conditions, item (D)(29) Details of Facility/Programme - Provisions on Early Redemption.

190 Ibid, item (D)(4) Details of Facility/Programme—Facility Description.

191 Ibid.

192 Ibid, item (D)(21)(a)(xi) Details of Facility/Programme-Details of Covenants-Positive Covenants-ASEAN GBS and the Guidelines on LOLA Framework on Sustainable and Responsible Investment (SRI) Sukuk Compliant.

193 Ibid, item (D)(22) Details of Facility/Programme-Details of Designated Account(s). This is required by standard 4.3 of the ASEAN Green Bond Standards.

194 Ibid, item (D)(21)(d)(iii) Details of Facility/Programme—Details of Covenants_Information Covenants. This is required by ASEAN Green Bond Standards, para 4.4 and SC LOLA Guidelines pt 3, para 7.08.

195 PNB Merdeka Ventures Sdn Berhad (n 176) 2. 
Instead, the issuer confirms that it will subsequently disclose to certificateholders the environmental sustainability objectives of the Office Tower, the process for determining how the Office Tower fits within the ASEAN Green Bond Standards' green categorization, and the eligibility criteria applied to identify and manage environmental and social risks associated with the Office Tower. ${ }^{196}$

PNBMV's Green Sukuk Framework was assessed by CICERO ${ }^{197}$ against ICMA's GBPs. CICERO assigned this framework a 'Medium Green' rating, reflecting 'projects and solutions that represent steps towards the long-term vision, but are not quite there yet'. ${ }^{198}$ As part of its assessment, CICERO noted that neither PNBMV nor PNB has a sustainability strategy, making it difficult to understand how the Green Sukuk Framework would support a broader corporate green strategy. ${ }^{199}$ CICERO also noted that green building certifications alone will not ensure energy efficient, low-carbon or carbonneutral buildings. ${ }^{200}$

Sukuk SKSB:

In January 2018, Sinar Kamiri Sdn Bhd (SKSB), a Malaysian company operating in the power generation business, ${ }^{201}$ issued a standalone issuance of RM245,000,000 (approximately USD61,000,000) worth of green sukuk (the 'Sukuk SKSB'). ${ }^{202}$

The contractual structure of the Sukuk SKSB is based on a wakalah and commodity murabaha arrangement. Unlike similar sukuk structures used by other Malaysian corporate issuers, a portion of the Sukuk SKSB issue proceeds is invested directly into a solar photovoltaic energy generating facility in Malaysia (the 'SKSB Project'), connecting certificateholders directly to that funded project. Pursuant to this arrangement, the sukuk trustee (MTrustee Berhad) acting on behalf of certificateholders appointed the issuer as agent under a wakalah agreement. ${ }^{203}$ The issuer issued Sukuk SKSB certificates and declared a trust in favour of certificateholders over the Sukuk SKSB issue proceeds and the assets acquired using those proceeds (the 'Wakalah Investments'). ${ }^{204}$ This gives certificateholders an undivided proportionate beneficial ownership interest in the Sukuk SKSB proceeds, the Wakalah Investments and the rights, title, interest, entitlement and benefit in, to and under the related transaction documents (the 'Sukuk SKSB Assets'). ${ }^{205}$ Pursuant to the wakalah agreement, the issuer (as agent) must invest at least 33 per cent

196 Sukuk PNBMV Programme, Principal Terms and Conditions, item (D)(21) item (d)(vi) Details of Facility/ProgrammeDetails of Covenants-Information Covenants.

197 Center for International Climate Research, “"Second Opinion” on PNB Merdeka Ventures Sdn. Berhad's Green Sukuk Framework’ (30 October 2017) <https://cicero.oslo.no/file/1238/PNBMV_2017.pdf> accessed 30 April 2019.

198 Ibid 5.

199 Ibid 11.

200 Ibid.

201 Sukuk SKSB, Principal Terms and Conditions, item (C)(10) Corporate Information of Issuer-Structure of Shareholdings and Names of Shareholders or, in the Case of a Public Company, Names of All Substantial Shareholders.

202 The Sukuk SKSB were issued in 17 tranches with maturities of between 2 and 18 years.

203 Sukuk SKSB, Principal Terms and Conditions, item (C)(4)(1) Details of Facility/Programme—Facility Description.

204 Ibid, item (C)(4)(2) Details of Facility/Programme-Facility Description.

205 Ibid. 
of the issue proceeds in the issuer's shari'ah-compliant business in respect of the SKSB Project. ${ }^{206}$ The balance of the Sukuk SKSB issue proceeds is invested in commodities under a commodity murabaha arrangement. ${ }^{207}$ Pursuant to this commodity murabaha, the issuer (on behalf of certificateholders) purchases commodities (through a subagent) for immediate cash payment at a price equal to the residue of the Sukuk SKSB issue proceeds. ${ }^{208}$ These commodities are then sold to the issuer (as buyer for itself) at a price equal to their original cost price plus pre-agreed profit margin, payable on a deferred basis. ${ }^{209}$ This cost price-plus-profit will equal the full outstanding principal amount and the aggregate expected periodic distributions with respect to the Sukuk SKSB. ${ }^{210}$ The commodities are then immediately on-sold for cash at their original cost price. ${ }^{211}$ For each tranche of Sukuk SKSB, the periodic distributions paid to certificateholders semiannually will be generated by the combined Wakalah Investments (which include the SKSB Project) and are capped at the periodic distribution amount agreed for each tranche of Sukuk SKSB. ${ }^{212}$ Any returns generated in excess of this amount will be kept by the issuer as an incentive fee. ${ }^{213}$

With respect to the SKSB Project itself, the issuer will use the cash generated from the sale of the commodities, together with the portion of the Sukuk SKSB issue proceeds invested directly in the issuer's shari'ah-compliant business, to part-fund costs associated with the design, construction, operation and maintenance of the SKSB Project. ${ }^{214}$ The issuer will also repay in full a loan facility used to fund the remaining part of the SKSB Project. ${ }^{215}$ To procure the construction of the SKSB Project, the issuer entered into an EPC contract with a contractor. ${ }^{216}$ It also entered into a power purchase agreement with TNB under which TNB will purchase the SKSB Project's future electricity output. ${ }^{217}$ In the event of cost overruns or a shortfall in the payments made by TNB due to any delay in payment, Mudajaya Group Berhad ('Mudajaya'), the issuer's ultimate parent, will provide an equity injection and/or intercompany financing facility to the issuer, providing certificateholders with a layer of capital protection. ${ }^{218}$

\footnotetext{
206 Ibid.

207 Ibid.

208 Ibid.

209 Ibid.

210 Ibid.

211 Ibid.

212 Ibid, item (C)(4)(3) Details of Facility/Programme—Facility Description.

213 Ibid.

214 Sukuk SKSB, Other Terms and Conditions, item (ii) Details on Utilisation of Proceeds by Issuer.

215 Ibid.

216 Sukuk SKSB, Other Terms and Conditions, item (x) Definitions-Definition of 'Project Agreements'.

217 Ibid.

218 Sukuk SKSB, Principal Terms and Conditions, item (C)(15) Details of Facility/Programme-Details of Security/Collateral Pledged.
} 
At maturity or early redemption of Sukuk SKSB certificates, ${ }^{219}$ the full amount due under the commodity murabaha will become payable. ${ }^{220}$ Concurrently with this, the issuer will repurchase, pursuant to a purchase undertaking, certificateholders' interest in the issuer's shari'ah-compliant business at market value on the relevant date. ${ }^{221}$ Once the outstanding principal amount of the Sukuk SKSB and any accrued but unpaid periodic distributions have been paid, the trust declared over the SKSB Sukuk Assets is dissolved and the Sukuk SKSB certificates are redeemed and cancelled. ${ }^{222}$

As with other sukuk issued in compliance with the SC's SRI Sukuk Standards, the terms and conditions for the Sukuk SKSB confirm that the issuer will periodically report on the use of proceeds from the issue of the Sukuk SKSB. ${ }^{223}$ The issuer also confirms that it has and will comply with all applicable laws, guidelines, permits and regulations, including relevant environmental laws, permits and guidance. ${ }^{24}$ From the documents publicly available, however, SKSB does not explicitly confirm that it will also comply with social, governance or recognized best practice standards relating to the SKSB Project. Instead, the annual report of Mudajaya confirms that its board of directors 'takes into consideration its environmental, social and governance impact ${ }^{225}$ when developing the company's corporate strategy and takes a 'proactive approach in managing potential environmental risks and impacts across the [Mudajaya] Group's operations'. ${ }^{226}$ The terms and conditions of the Sukuk SKSB also do not disclose the impact objectives of the SKSB Project but include an undertaking by the issuer to periodically report on these impact objectives where feasible and to the extent possible. ${ }^{227}$ These characteristics of the Sukuk SKSB were sufficient for the Malaysian agency, RAM Consultancy Services Sdn Bhd (RAM) to confirm in its second opinion that SKSB's Green Sukuk Framework aligned with both the SC's SRI Sukuk Standards and ICMA's GBPs. ${ }^{228}$ Due, perhaps, to the less detailed disclosure provided by the issuer in the terms and conditions of the Sukuk SKSB as compared with other responsible finance sukuk, RAM's second opinion

219 Whether at the issuer's initiative or following the occurrence of a dissolution event (referred to in the Sukuk SKSB Principal Terms and Conditions as an event of default—such as non-payment of any amount payable by the issuer under the Sukuk SKSB), Sukuk SKSB, Principal Terms and Conditions, item (C)(26) Details of Facility/Programme-Events of Defaults or Enforcement Events, where applicable, including recourse available to investors and Sukuk SKSB, Principal Terms and Conditions, item (C)(29) Details of Facility/Programme-Provisions on Early Redemption. While the Sukuk SKSB, Principal Terms and Conditions do not explicitly provide that a failure to invest in the SKSB Project will be a dissolution event, it does contain a negative covenant restricting the issuer's ability to alter the use of proceeds of the Sukuk SKSB, Sukuk SKSB, Principal Terms and Conditions, item (C)(21) Details of Covenants.

220 Ibid, item (C)(4)(4) Details of Facility/Programme-Facility Description.

221 Ibid, item (C)(4)(2) Details of Facility/Programme - Facility Description; ibid, item (C)(26) Details of Facility/ProgrammeEvents of Defaults or Enforcement Events, where applicable, including recourse available to investors. In the case of any total loss of the SKSB Project, the issuer will use the applicable insurance proceeds to repay the amounts outstanding on the Sukuk SKSB. Sukuk SKSB, Principal Terms and Conditions, item (C)(4)(2) Details of Facility/Programme-Facility Description.

222 Ibid, item (C)(4)(4) Details of Facility/Programme-Facility Description.

223 Ibid, item $(\mathrm{C})(21)(\mathrm{d})(\mathrm{h})$ Details of Covenants_Information Covenants.

224 Ibid, item (C)(25)(o) Details of Covenants-Representations and Warranties.

225 Mudajaya Group Berhad, 'Annual Report 2016' (2017) s 1.4.

226 Ibid.

227 Sukuk SKSB, Principal Terms and Conditions, item (C)(21) item (d)(h)(iv) Details of Covenants_Information Covenants.

228 RAM Consultancy Services Sdn Bhd, 'Sinar Kamiri Sdn Bhd Green SRI Sukuk, Proposed Sukuk Issuance of RM245.0 Million; Second Opinion Report' (2 November 2017). 
includes an element of conjecture and it provides, for example, RAM's opinion on the likely impact of the SKSB Project. ${ }^{229}$ Nevertheless, based on its review of the SKSB Green Sukuk Framework, RAM assigned the Sukuk SKSB a Tier-1 Environmental Benefit rating, the highest of the three tiers of ratings that it assigns. ${ }^{230}$

Indonesian Green Sukuk:

In February 2018, the Republic of Indonesia (the 'Republic') became the first sovereign to issue responsible finance sukuk with its issue of USD1,250,000,000 worth of green sukuk (the '2018 Indonesian Green Sukuk') under a sukuk issuance programme (the 'Indonesian Sukuk Programme'). ${ }^{231}$ In February 2019, the Republic again accessed the Islamic capital markets with the issue of USD750,000,000 worth of green sukuk (the '2019 Indonesian Green Sukuk' and, together with the 2018 Indonesian Green Sukuk, the 'Indonesian Green Sukuk'). ${ }^{232}$ The Indonesian Green Sukuk were issued through an SPV (Perusahaan Penerbit SBSN Indonesia III or PPSI-III) and were listed on Nasdaq Dubai and the Singapore Exchange as part of separate international offerings. They were the first two series of sukuk to be issued under the Republic's Green Bond and Green Sukuk Framework. ${ }^{233}$

The Indonesian Sukuk Programme facilitates the issue of sukuk based on either an ijarah or a wakalah contractual structure, ${ }^{234}$ with the wakalah structure chosen for the Indonesian Green Sukuk. ${ }^{235}$ Pursuant to this structure, PPSI-III issued sukuk certificates to certificateholders and used 51 per cent of the issue proceeds to purchase beneficial rights in and to certain properties from the Republic (the 'Ijarah Assets'). ${ }^{236}$ The balance of the issue proceeds were used to purchase beneficial rights in and to certain assets from the Republic and to procure the construction and delivery of such assets (the 'Project Assets' and, together with the Ijarah Assets, the 'Indonesian Sukuk Assets'). ${ }^{237}$ PPSI-III declared a trust in favour of certificateholders over all of its rights, title, interest and

229 Ibid 9.

230 Ibid 2.

231 Pricing Supplement dated 22 February 2018 for the issue by Perusahaan Penerbit SBSN Indonesia III of USD1,250,000,000 3.75\% Trust Certificates due 2023 under the USD25,000,000,000 Trust Certificate Issuance Program (the '2018 Indonesian Green Sukuk Pricing Supplement').

232 Pricing Supplement dated 12 February 2019 for the issue by Perusahaan Penerbit SBSN Indonesia III of USD750,000,000 3.90\% Trust Certificates due 2024 under the USD25,000,000,000 Trust Certificate Issuance Program (the '2019 Indonesian Green Sukuk Pricing Supplement').

233 Offering Memorandum dated 23 January 2018, Indonesian Sukuk Programme, Appendix, The Green Bond and Green Sukuk Framework and Offering Memorandum dated 31 January 2019, Indonesian Sukuk Programme, Appendix The Green Bond and Green Sukuk Framework.

234 Offering Memorandum dated 23 January 2018, Indonesian Sukuk Programme, 2 Structure Diagram and Cash Flows and Offering Memorandum dated 31 January 2019, Indonesian Sukuk Programme, 2 Structure Diagram and Cash Flows.

2352018 Indonesian Green Sukuk Pricing Supplement, pt A, Item 18 and 2019 Indonesian Green Sukuk Pricing Supplement, pt A, Item 18.

236 For example, on the date of issuance of the 2018 Indonesian Green Sukuk, the total Ijarah Assets invested in were valued at Indonesian Rupiah (IDR) 8,547,793,088,667 (converted at the average IDR/USD exchange rate for January 2018, as set out on page (v) of the Offering Memorandum dated 23 January 2018, Indonesian Sukuk Programme, this represented a value equivalent to approximately USD636,849,433 or 51\% of the proceeds from the issue of the 2018 Indonesian Green Sukuk).

237 For example, on the date of issuance of the 2018 Indonesian Green Sukuk, the total Project Assets invested in were valued on the date of issuance of the Indonesian Green Sukuk at IDR8,207,526,467,700 (converted at the average IDR/USD exchange rate for January 2018, as set out on page (v) of the Offering Memorandum dated 23 January 2018, Indonesian Sukuk Programme, this represented a value equivalent to approximately USD611,498,023 or 49\% of the proceeds from the issue of the 2018 Indonesian Green Sukuk). 
benefit in, to and under the Indonesian Sukuk Assets, the related transaction documents, all monies standing to the credit of a specified account and all connected proceeds. ${ }^{238}$ As a result, PPSI-III holds these assets on trust absolutely for certificateholders. ${ }^{239}$ PPSI-III (as lessor) then leases the Ijarah Assets to the Republic and, following completion and delivery of the Project Assets, will also lease these to the Republic. ${ }^{240}$ The amount payable periodically from the lease of the Ijarah Assets will be an amount equal to the pre-agreed periodic distributions payable to certificateholders during the tenor of the Indonesian Green Sukuk. ${ }^{241}$ Pursuant to a wakalah agreement, the Republic has been delegated responsibility for collecting all rental payments due (from itself as lessee), insuring the properties making up the Indonesian Sukuk Assets, paying property taxes and performing major maintenance and structural repairs of those properties. ${ }^{242}$

Although tangible and income-generating, the Indonesian Sukuk Assets are not the green projects that will ultimately be funded through the issue of the Indonesian Green Sukuk. Instead, with cash received from the purchase of the Indonesian Sukuk Assets by PPSI-III, the Republic will finance or refinance expenditure relating directly to green projects. ${ }^{243}$ Consistent with the trend seen in the majority of other responsible finance sukuk, therefore, certificateholders do not invest directly in the funded projects but do so indirectly through an intermediary contractual structure. As part of the offering documents for each series of Indonesian Green Sukuk, no specific eligible projects were disclosed. Projects to be funded are instead to be determined following issue of the Indonesian Green Sukuk by reference to the requirements of the Republic's Green Bond and Green Sukuk Framework. ${ }^{244}$ In order to be an eligible project within this framework, a project must be identified for budget allocation based on its ability to address climate change mitigation and adaptation. ${ }^{245}$ The project must then fall within at least one of a number of specified sectors, which include renewable energy and sustainable agriculture. ${ }^{246}$ Projects related to fossil fuel-based electric power generation, large-scale hydropower plants and nuclear or nuclear-related assets are not eligible under the framework. ${ }^{247}$ The Republic, acting through the Ministry of Finance, undertakes to

238 Offering Memorandum dated 23 January 2018, Indonesian Sukuk Programme, Condition 4.1 Summary of the Trust and Offering Memorandum dated 23 January 2019, Indonesian Sukuk Programme, Condition 4.1 Summary of the Trust.

239 Ibid.

240 Offering Memorandum dated 23 January 2018, Indonesian Sukuk Programme, 63 Summary of the Principal Transaction Documents_Lease Agreement and Offering Memorandum dated 31 January 2019, Indonesian Sukuk Programme, 62 Summary of the Principal Transaction Documents-Lease Agreement.

241 Ibid.

242 Ibid, 64 and 65, Summary of the Principal Transaction Documents-Servicing Agency Agreement and Wakala Agreement, and 63 and 64, Summary of the Principal Transaction Documents—Servicing Agency Agreement and Wakala Agreement.

2432018 Indonesian Green Sukuk Pricing Supplement, pt A Use of Proceeds and 2019 Indonesian Green Sukuk Pricing Supplement, pt A Use of Proceeds. A failure to invest in eligible projects will not result in the early redemption of the Indonesian Green Sukuk.

244 Ibid.

245 Offering Memorandum dated 23 January 2018, Indonesian Sukuk Programme, Appendix, The Green Bond and Green Sukuk Framework, s II(2) and Offering Memorandum dated 31 January 2019, Indonesian Sukuk Programme, Appendix, The Green Bond and Green Sukuk Framework, s II(2).

246 Ibid, Appendix, The Green Bond and Green Sukuk Framework, s II(1).

247 Ibid, Appendix, The Green Bond and Green Sukuk Framework, s II(1). 
report annually on the use of the issue proceeds and the estimated beneficial impact of the funded projects. ${ }^{248}$ This annual report and the continued compliance of the Indonesian Green Sukuk with the Republic's Green Bond and Green Sukuk Framework will be verified by an independent third party. ${ }^{249}$

In order to ensure that on redemption of the Indonesian Green Sukuk certificates all amounts due are repaid to certificateholders, the Republic confirmed pursuant to a unilateral undertaking that at maturity or upon early redemption ${ }^{250}$ of the Indonesian Green Sukuk, it will purchase all of PPSI-III's rights, title, interest and benefit in, to and under the Indonesian Sukuk Assets at a price equal to the outstanding principal amount of the relevant series of Indonesian Green Sukuk, plus any accrued but unpaid periodic distributions. ${ }^{251}$ Once the Indonesian Sukuk Assets have been repurchased, the certificates will be redeemed and the trust declared by PPSI-III in favour of certificateholders will be dissolved. ${ }^{252}$

CICERO provided a second opinion on the Republic's Green Bond and Green Sukuk Framework. ${ }^{253}$ This confirmed that the framework aligns with ICMA's GBPs, the ASEAN Green Bond Standards and the Regulation on the 'Issuance and the Terms of Green Bond' published by the Republic's Financial Services Authority. ${ }^{254}$ CICERO assigned the Green Bond and Green Sukuk Framework a rating of 'Medium Green'. ${ }^{255}$ While noting the support that the framework will provide to the Republic with respect to meeting its greenhouse gas emission reduction targets, CICERO highlighted the possibility that some eligible projects may include an element of deforestation. ${ }^{256}$ The Republic provided assurances that this would not happen in the context of sustainable agriculture ${ }^{257}$ however, a failure of the Republic to comply with these assurances would not result in the early redemption of the Indonesian Green Sukuk certificates. $^{258}$

\footnotetext{
248 Ibid, s II(4).

249 Ibid, s III.

250 Upon the occurrence of a dissolution event, ibid, Condition 9.2 Dissolution Following a Dissolution Event and Condition 9.4, No Other Dissolution. In the case of a total loss with respect to the properties underlying the Indonesian Sukuk Assets, the amount payable to investors will be funded using insurance proceeds, ibid, Condition 9.3, Dissolution Following a Total Loss Event.

251 Ibid, Condition 9 Capital Distributions of the Trust.

252 Ibid.

253 Center for International Climate Research, "'Second Opinion” on The Republic of Indonesia’s Green Bond and Green Sukuk Framework' (3 January 2018).

254 The Republic of Indonesia's Financial Services Authority has published a regulation on the 'Issuance and the Terms of Green Bond' (Financial Services Authority Regulation 60 /POJK.04/2017). However, this regulation refers to 'green bonds' and 'debt securities' rather than referring to sukuk, and there is no indication in the regulation that the reference to 'bond' is to be given a broader meaning of also including sukuk.

255 Center for International Climate Research (n 253) 2.

256 Ibid 16 and 17.

257 Ibid 17.

258 Offering Memorandum dated 23 January 2018, Indonesian Sukuk Programme, 19 Investment Considerations-where the proceeds of a series are specified as being used to finance or refinance Eligible Green Projects, as defined under the Green Bond and Green Sukuk Framework, such certificates may not be suitable for environmentally focused prospective investors and Offering Memorandum dated 31 January 2019, Indonesian Sukuk Programme, 18 Investment Considerations-where the proceeds of a series are specified as being used to finance or refinance Eligible Green Projects, as defined under the Green Bond and Green Sukuk Framework, such certificates may not be suitable for environmentally focused prospective investors. Concern over the ultimate use of proceeds from the issue of the Indonesian Green Sukuk has been highlighted by some commentators. See, for example, Morgan Davis, 'Indonesia's
} 


\section{HSBC Amanah Sustainability Sukuk:}

Finally, in October 2018, HSBC Amanah Malaysia Berhad ('HSBC Amanah') issued RM500,000,000 (approximately USD120,000,000) worth of sustainability sukuk (the 'HSBC Amanah Sustainability Sukuk') ${ }^{259}$ under its existing multi-currency sukuk programme (the 'HSBC Amanah Sukuk Programme'). ${ }^{260}$ This was the first issuance of sukuk certificates to identify the United Nations' Sustainable Development Goals (SDGs) as the framework to align with when determining the eligible projects into which the sukuk proceeds will ultimately be invested. ${ }^{261}$

Sukuk issuances under the HSBC Amanah Sukuk Programme are based on a wakalah and commodity murabaha contractual structure. ${ }^{262}$ For the HSBC Amanah Sustainability Sukuk, Malaysia Trustees Berhad (acting as trustee for the certificateholders) appointed HSBC Amanah as agent (or wakeel) for the purchase and sale of tangible assets in the form of HSBC Amanah's Islamic financing assets and for the purchase and sale of commodities. ${ }^{263}$ In preparation for the issuance of the HSBC Amanah Sustainability Sukuk, the trustee requested HSBC Amanah (as agent) to purchase on behalf of the trustee the beneficial ownership of pre-identified tangible assets from HSBC Amanah (as issuer). ${ }^{264}$ At the same time, the issuer requested the trustee to sell commodities to the issuer. ${ }^{265}$ The issuer then issued HSBC Amanah Sustainability Sukuk certificates, and the trustee declared a trust in favour of certificateholders over the HSBC Amanah Sustainability Sukuk issue proceeds and the assets acquired using those proceeds. ${ }^{266}$ This gives the certificateholders an undivided proportionate beneficial ownership interest in the tangible assets and any commodities purchased. ${ }^{267}$ However, like many of the previous issuances of responsible finance sukuk, HSBC Amanah Sustainability Sukuk certificateholders do not receive a proportionate ownership interest in the sustainable projects ultimately being funded. Using a minimum of 10 per cent of the HSBC Amanah Sustainability Sukuk issue proceeds, HSBC Amanah (as agent on behalf of the trustee) purchased the tangible assets from HSBC Amanah (as issuer). ${ }^{268}$ Income generated by these tangible assets during the tenor of the sukuk will be

Green Sukuk Needs a Harder Look' (Global Capital Asia, 27 February 2018) <https://www.globalcapital.com/article/ b173hzfxhv8p0f/indonesias-green-sukuk-needs-a-harder-look> accessed 30 April 2019.

259 RM500,000,000 4.3\% Sustainability Sukuk due 2023.

260 The RM3 billion Multi-Currency Sukuk Programme.

261 United Nations Development Programme, 'HSBC Amanah Malaysia Issues World's First SDG Sukuk' (3 October 2018), $<$ https://www.undp.org/content/undp/en/home/news-centre/news/2018/HSBC_Amanah_Malaysia_issues_worlds_first_United_ Nations_Sustainable_Development_Goals_sukuk.html> accessed 30 April 2019.

262 HSBC Amanah Malaysia Berhad, Information Memorandum dated 5 September 2012 for the multi-currency sukuk programme of up to RM3 billion in nominal value (or its equivalent in foreign currencies) (the 'HSBC Amanah Information Memorandum') s 2, item (2.0)(b) Principal Terms and Conditions of the Sukuk-Facility Description.

263 HSBC Amanah Information Memorandum, s 2, item (2.0)(b)(1) Principal Terms and Conditions of the Sukuk-Facility Description.

264 Ibid s 2, item (2.0)(b) (2) Principal Terms and Conditions of the Sukuk-Facility Description.

265 Ibid s 2, item (2.0)(b) (3) Principal Terms and Conditions of the Sukuk-Facility Description.

266 Ibid s 2, item (2.0)(b) (4) Principal Terms and Conditions of the Sukuk-Facility Description. See also Trust Deed dated 20 September 2012 between HSBC Amanah Malaysia Berhad and Malaysian Trustees Berhad, s 1A.1.

267 Trust Deed dated 20 September 2012 between HSBC Amanah Malaysia Berhad and Malaysian Trustees Berhad, s 1A.5(a). 268 HSBC Amanah Information Memorandum, s 2, item (2.0)(b)(2) Principal Terms and Conditions of the Sukuk-Facility Description. 
retained by the issuer as an incentive fee for its services as agent. ${ }^{269}$ The remaining balance of the issue proceeds was used by the trustee to purchase commodities from a commodities broker. $^{270}$ These commodities were sold to HSBC Amanah (as issuer) for a price equal to their original cost price plus a pre-agreed profit margin, payable on a deferred basis. Upon completion of this purchase, HSBC Amanah on-sold these commodities for cash at their original cost price. During the tenor of the HSBC Amanah Sustainability Sukuk, the profit element of this deferred price will be distributed to the certificateholders semi-annually as periodic distributions. ${ }^{271}$

At maturity or early redemption ${ }^{272}$ of the HSBC Amanah Sustainability Sukuk, the issuer will, pursuant to a purchase undertaking, repurchase the tangible assets at their original sale price and will also repay the full amount due under the commodity murabaha with respect to the commodities. ${ }^{273}$ These amounts will be used to repay to certificateholders the outstanding principal amount of the HSBC Amanah Sustainability Sukuk, together with accrued but unpaid periodic distributions. Following repayment to certificateholders, the HSBC Amanah Sustainability Sukuk certificates will be redeemed and cancelled. ${ }^{274}$

The cash generated from the sale of the tangible assets and commodities provides HSBC Amanah with an amount equivalent to the issue proceeds of the HSBC Amanah Sustainability Sukuk. As the HSBC Amanah Sustainability Sukuk certificates are issued under a sukuk programme that was not established specifically for the issue of responsible finance sukuk, the use of proceeds in the underlying programme documentation simply notes that the issuer shall use the proceeds from the issue of sukuk under the HSBC Amanah Sukuk Programme as 'working capital in the ordinary course of [HSBC Amanah's] Islamic banking business ... [and] all utilisation of proceeds from the issuance of the Sukuk shall be Shariah compliant'. ${ }^{275}$ However, the issuer has confirmed that the HSBC Amanah Sustainability Sukuk issue proceeds will ultimately be used to finance eligible projects and businesses in line with HSBC's Sustainable Development Goal (SDG) Bond Framework, ${ }^{276}$ which include those contributing to achieving good health and well-being, quality education, clean water and sanitation, and sustainable cities and communities. ${ }^{277}$ This framework is based on, and aligns with, the United Nations'

\footnotetext{
269 Ibid s 2, item (2.0)(b) (7) Principal Terms and Conditions of the Sukuk-Facility Description.

270 Ibid s 2, item (2.0)(b) (3) Principal Terms and Conditions of the Sukuk-Facility Description.

271 Ibid s 2, item (2.0)(b) (7) Principal Terms and Conditions of the Sukuk-Facility Description.

272 Upon the occurrence of a dissolution event (referred to in the HSBC Amanah Information Memorandum as an event of default), such as non-payment. HSBC Amanah Information Memorandum, s 2, item (2.0)(s) Principal Terms and Conditions of the Sukuk-Events of default.

273 HSBC Amanah Information Memorandum, s 2, item (2.0)(b)(8) Principal Terms and Conditions of the Sukuk-Facility Description.

274 Trust Deed dated 20 September 2012 between HSBC Amanah Malaysia Berhad and Malaysian Trustees Berhad, s 1A.12.

275 HSBC Amanah Information Memorandum, s 2, item (2.0)(j) Principal Terms and Conditions of the Sukuk-Details on Utilisation of Proceeds.

276 HSBC, 'HSBC Sustainable Development Goal (SDG) Bond Framework' (November 2017) <https://www.hsbc.com/investors/ fixed-income-investors/green-and-sustainability-bonds $>$ accessed 30 April 2019. See also, HSBC Amanah Malaysia Berhad, Financial Statements for the Period Ending 31 December 2018, 21.

277 The pricing supplement for this issuance is not publicly available, however, see United Nations Development Programme, 'HSBC Amanah Malaysia Issues World's First SDG Sukuk' (3 October 2018) <https://www.undp.org/content/undp/en/home/ news-centre/news/2018/HSBC_Amanah_Malaysia_issues_worlds_first_United_Nations_Sustainable_Development_Goals_sukuk.
} 
SDGs and has already been used as the investment framework for the issue of conventional sustainable bonds by HSBC Holdings plc. ${ }^{278}$

While no second opinion was provided specifically for the issue of the HSBC Amanah Sustainability Sukuk, Sustainalytics provided a second opinion on HSBC's Sustainable Development Goal Bond Framework in 2017. In its second opinion, Sustainalytics confirmed that HSBC's Sustainable Development Goal Bond Framework aligned with ICMA's GBPs, SBPs and Sustainability Bond Guidelines and that the eligible categories for use of proceeds are recognized as being impactful by the GBPs and SBPs. ${ }^{279}$

\section{Islamic finance and responsible finance-a natural match?}

Islamic law's inherent ethical framework has been cited by commentators to highlight an innate congruence between Islamic finance and responsible finance. As a financial sector whose very existence is based on interpretations of religious teachings and whose purpose is, at least in theory, to pursue not just material gains but broader extra-financial objectives, Islamic finance does appear to share conceptual similarities with conventional responsible finance.

In the context of Islamic finance as it operates today, structural compliance with Islamic legal prohibitions of riba, gharar, maysir and haram activities represents a form of visible adherence to rules of Islamic law and ensures that Islamic finance products and services are contractually distinguishable from their conventional counterparts. At the same time, contemporary Islamic finance has faced criticism for falling short of Islamic law's enduring ethical benchmarks and for failing to uphold the spirit of Islamic finance's religious underpinnings by replicating the economic substance of conventional finance instead. ${ }^{280}$ In practice, the application of Islamic law to modern financial transactions has generally manifested itself in formal compliance with that law through the structural avoidance of prohibited activities, rather than in explicitly striving to achieve broader ethical objectives or societal well-being. ${ }^{281}$ Reflecting on this, Asutay notes that Islamic finance has 'been pursuing policies away from the theoretical underpinnings and systemic understanding of Islamic economics and has located a surrogate financial framework in

html > accessed 30 April 2019; HSBC, 'HSBC Reaches a Quarter of its \$100 Billion Sustainable Finance Target in the First Year' (26 November 2018) 2; RAM Ratings Services Berhad, 'RAM Ratings Rates World's First SDG Sukuk by HSBC Amanah' (Press Release, 8 October 2018) <https://www.ram.com.my/pressrelease/?prviewid=4719> accessed 30 April 2019.

278 HSBC Holdings plc's USD1,000,000,000 sustainability bonds due 2023.

279 Sustainalytics, HSBC Sustainable Development Goals (SDG) Bond: Second-Party Opinion by Sustainalytics (Sustainalytics 2017) 3-9.

280 Habib Ahmed, Product Development in Islamic Banks (Edinburgh University Press 2011) 2-4, outlining commentary on the matter. The Malaysian central bank (Bank Negara Malaysia) has recently issued guidance documents on 'value-based intermediation' with the aim of reorienting Islamic finance business models 'towards the objectives of Shariah that generate positive and sustainable impact to the economy, community and environment through practices, processes, offerings and conduct', Bank Negara Malaysia, 'Guidance Documents on Value-Based Intermediation: Strengthening the Roles and Impact of Islamic Finance' (Bank Negara Malaysia, 3 October 2018), <http://www.bnm.gov.my/index.php?ch=en_announcement\&pg=en_ announcement\&ac $=670>$ accessed 30 April 2019.

281 Valentino Cattelan, 'Islamic Finance and Ethical Investments: Some Points of Reconsideration' in M Fahim Khan (ed), Islamic Banking and Finance in the European Union (Edward Elgar Publishing Limited 2010) 76, 77; Haider Ala Hamoudi, 'The Muezzin's Call and the Dow Jones Bell: On the Necessity of Realism in the Study of Islamic Law' (2008) 56(2) American Journal of Comparative Law 423, 460. 
neo-classical economics' ${ }^{282}$ The implication of this ideological struggle within Islamic finance, and the reality that some financial transactions will simply be social valueneutral, is that the practice of contemporary Islamic finance cannot always be described as synonymous with responsible finance just because of its connection with a religion. ${ }^{283}$

However, the recent development of responsible finance sukuk arguably represents a movement towards a more overt emphasis on social and ethical concepts in Islamic finance transactions. These instruments have been consciously structured to address the requirements of both the Islamic and responsible finance markets, rather than naturally fitting within one market simply because of adherence to the rules applicable to the other. As is the case with conventional responsible finance, there is an intentionality behind responsible finance sukuk to pursue positive extra-financial objectives and to consider the broader consequences of a transaction. This is something that some have suggested is not currently present in the Islamic finance market more generally. Actively providing capital on the basis that it will ultimately be used to fund projects with environmentally friendly and/or socially conscious objectives arguably aligns with normative principles of common good, justice and respect for God's creation that are advocated in Islamic law. ${ }^{284}$ In this way, responsible finance sukuk that are specifically structured to combine the objectives of positive societal effect, compliance with Islamic law and attainment of monetary rewards could provide Islamic finance with a mechanism that goes beyond simply formal adherence to Islamic law. Instead, the dual pursuits of positive financial and extra-financial outcomes place responsible finance sukuk as a class of financial product through which Islamic finance market participants may move closer to implementing broader notions of societal benefit and communal well-being, while still being able to generate financial returns. These financial instruments could, therefore, go some way towards bridging the gap between the aspirational ideals and the practice of Islamic finance today. ${ }^{285}$

Responsible finance sukuk are not, of course, the solution to all of the criticisms directed at contemporary Islamic finance and a pursuit of extra-financial outcomes alone will not automatically address broader structural concerns raised by industry commentators. Criticisms that the sukuk market more broadly has faced, such as its use of debtlike contractual structures and profit-smoothing mechanisms to protect certificateholders

282 Mehmet Asutay, 'Conceptualization of the Second Best Solution in Overcoming the Social Failure of Islamic Finance: Examining the Overpowering of Homo Islamicus by Homo Economicus' (2007) 15(2) IIUM Journal of Economics and Management 167, 169.

283 Cattelan (n 281) 80.

284 Ibid 106, discussing the connection between Islamic finance and 'green' financing.

285 Securities Commission Malaysia, 'Innovation in the Sukuk Market: Recent Regulatory and Market Initiatives' (January-June 2015) 10(1) Malaysian ICM 19, 19 noting that '... innovation in sukuk is driven by the growing calls for Islamic finance to embrace the true objectives of Shariah (maqasid al-Shariah), to ensure that the core values embedded in the maqasid al-Shariah are reflected in such products. This includes incorporating sustainable values towards the environment and society by ensuring Islamic finance incorporate environment, social and governance (ESG) principles and are accessible to a larger segment of society.' Dalal Aassouli and others, 'Green Sukuk, Energy Poverty, and Climate Change; A Roadmap for Sub-Saharan Africa' (World Bank Group, December 2018) Policy Research Working Paper 8680, 19 <http://documents.worldbank.org/curated/en/595861545145005026/pdf/ WPS8680.pdf $>$ accessed 30 April 2019. 
from project risk and to safeguard their capital, ${ }^{286}$ all remain valid with respect to the responsible finance sukuk issued to date. Reflecting this, the responsible finance sukuk market has shown a distinct preference for sukuk structures based entirely or predominantly on commodity murabaha arrangements that guarantee periodic returns and repayment of capital. The majority of responsible finance sukuk also reflect some level of contractual separation between certificateholders and the funded project. As a result, while the sukuk issue proceeds may ultimately be invested in a project with positive green or social characteristics, by subscribing for the sukuk certificates, certificateholders are typically not themselves investing directly in that project nor does the project's economic performance solely determine those certificateholders' returns. Even in responsible finance sukuk where certificateholders are granted some level of ownership interest in the funded project (such as in the Sukuk Tadau and Sukuk SKSB), the contractual structure and credit enhancements in place safeguard payment of pre-agreed returns on a periodic basis and ultimate repayment of certificateholders' capital.

This current dominance of responsible finance sukuk based on commodity murabaha arrangements is likely to be reflective of the disproportionately large number of Malaysian issuers of these instruments. Growing concerns among Islamic scholars (particularly outside of the Malaysian financial market) over the Islamic finance market's over-reliance on commodity murabaha contracts could result in a reduction of responsible finance sukuk structures based on these contracts as the market expands beyond Malaysia. A move away from predominantly commodity murabaha arrangements outside of Malaysia has already been seen in the Indonesian Green Sukuk, which used a wakalah structure to invest in income generating assets in order to generate periodic distributions and to fund the repayment of capital on redemption of the sukuk certificates. ${ }^{287}$

The extent to which certificateholders will be willing to assume more project risk as the responsible finance sukuk market matures, is, however, more uncertain. Contractual separation between certificateholders and the funded projects protects certificateholders from the risks associated with investing directly in a project and allows these instruments to function in a way that is economically similar to conventional bonds. This protection reflects current expectations of certificateholders in the contemporary sukuk market. ${ }^{288}$ As a result, the extent to which this aspect of the responsible finance sukuk market will change may depend on a more general reassessment of certificateholders' willingness to accept project risk as part of their sukuk investments.

\section{Conclusion}

Although the first responsible finance sukuk certificates were issued in 2014, it has only been from the second half of 2017 that the responsible finance sukuk market has started to gain momentum. As a result, the number of issuances of responsible finance sukuk

286 Moghul (n 32) 171, for a discussion of these criticisms in the context of the sukuk market.

287 Similarly, the very recent MAF Sukuk is based primarily on a wakalah structure.

288 Moghul, ibid 172. 
remains small and largely localized in Asian markets. The recent issue of green sukuk by the Republic of Indonesia may be the step needed to bring responsible finance sukuk to the broader sukuk market and to act as a benchmark for future international issuances. ${ }^{289}$

Other than the Sukuk Ihsan, whose step-down returns mechanism distinguishes these sukuk from other responsible finance instruments, the economic effect of responsible finance sukuk issued to date has largely aligned with that of responsible finance bonds. Like responsible finance bonds, responsible finance sukuk have generally been structured to protect certificateholders from the risks associated with the funded project. In order to achieve this, while still complying with financial principles of Islamic law, responsible finance sukuk have generally involved a layered contractual structure in which certificateholders invest in a contact that will generate periodic distributions and return of capital on redemption, while the issuer or obligor then uses the money that has been channelled through this contract to invest in a green or social project. Notwithstanding this contractual separation, the distinguishing feature of responsible finance sukuk is always the deliberate use of proceeds generated through the sukuk structure to ultimately (even if indirectly) fund projects meeting specified extra-financial benchmarks. These instruments intentionally add an additional level of consideration to a financial transaction beyond simply the impact of that transaction on its participants. Instead, responsible finance sukuk enable transaction participants to consider the instrument's broader societal consequences.

In practice, the product-defining need for the proceeds from an issue of responsible finance sukuk to be invested in projects that comply with Islamic law and align with predetermined environmental and/or social benchmarks may restrict the types of entities that can raise capital through the issue of these instruments. As a result, while responsible finance sukuk may develop as a segment of the sukuk market more generally, they are unlikely to emerge as a successor to the current sukuk structures used. Yet in the context of an Islamic finance market that has been criticized for disengaging with its ethical framework and religious underpinnings, the development of responsible finance sukuk may represent a step towards reconciling the theory of Islamic finance with its practice. With the growing use of these instruments, then, issuers and investors in the Islamic finance market may now be able to participate in financial transactions that not only comply with Islamic law in legal form but also facilitate an active pursuit of positive societal objectives. 